\section{PRESIDENCIALISMO E PARLAMENTARISMO NA IDEOLOGIA DE RUI BARBOSA *)}

\section{Paulo Brossard de Souza Pinto}

o Rio Grande do Sul sempre foi o lugar e o clima mais propicio à discussão das formas. Es perou-se dêle essa contribuicão à estrutura do pais; pas 1930 e 1946 não permitiram reflexão em tôrno aêsses problemas.

Pontes de Miranda

$$
\text { de uma cairta-parecer ao sr. Raul Pilla. }
$$

o recuo dos nossos jurisconsultos foi, portanto êtro contra tôdas as regras da transmissão evolução da doutrina jurídica.

RUI BARBOSA.

"Posse dos direitos pessoais."

Rui Barbosa não deixou sistematizado seu ideário jurídico, políico, artístico ou filosófico-religioso, divulgado "em meio-século de uma carreira pública incessantemente ativa." 1)

Para que seja preciso em tôrno a determinado assunto, é mister se faça uma espécie de colheita pela seara quase imensurável da sua produção, recolhendo-se, preliminarmente, o que se relacionar ao tema eleito, valorizando-se após os elementos à vista das fases da sua vida e dos momentos históricos em que foram externados, medindo e

*) Trabalho enviado ao Congresso de Direito Constitucional que em homenagem a

1) Rui - Entrevista ao "Correio do Povo", in "Campanha presidencial", 1919, pág. 5. ista Pereira - "Diretrizes de Rui Barbosa", 1932, pref., pág. 9- "A imensa obra de Rui Barbosa ressente-se da falta de uma síntese, em que êle proprio

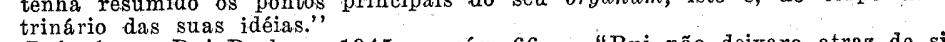
Luiz Delgado - Rui Barbosa, 1945 - pág. 66 - "Rui não deixara atraz de si um livro plàcidamente escrito onde se buscassem as suas idéias, expostas co pesando o caráter de generalidade ou de particularidade que ofere çam. Ter-se-á ainda de considerar que a existência de Rui decorreu entre a idade áurea do liberalismo e a do seu declínio, quando, de um lado, a reação evocava "o carcomido nume do Estado arquipotente" contra o "Estado reto, limitado e justo" 2) e, de outro, um "sôpro de socialização" agitava o mundo, fazendo com que as "constituições que ainda (têm) tivessem por norma as declarações de direitos consagrados no século dezoito" já não correspondessem "exatamente à consciência jurídica do universo." 3 )

Assim como se descobre mais de uma fase na simples evolução do eui estilo, surpreende-se no corpo das suas idéias diversos momentos, refletindo retificações de atitudes dantes assumidas. ${ }^{4}$ )

Ao demais, a si próprio fêz êste reparo: "os frutos da minha vida são escassos e tristes, bem que os meus ideais tenham sido grandes e belos." 5)

Espírito altamente afeito ao trato dos livros, tinha-se "por feliz em não ser um dêsses homens, a quem o tempo e a experiência nada ensinam." $\left({ }^{6}\right)$

E embora as suas idéias fundamentais tenham permanecido imu tåveis e fiel a elas a sua vida, traçada entre o direito e a liberdade, na frase sugestiva de Alcindo Guanabara, numerosas foram as variações quanto ao modo de realizá-las. ${ }^{7}$ )

E no setor jurídico-político o ordinário é a mudança com o evoluir dos problemas.

Êle mesmo sentenciou: "é dos homens políticos mudar; mudar é também dos filósofos, é também dos juristas, é de todos os espíritos humanos." 8)

Aliás, "as contradições de um homem com o seu passado não incorrem justamente em censura, senão quando caminham do bem para

2) Rui - Correspondência íntima - 2.a ed. de Afonso Rui, pág. 400 v. in "Ditacaura e República", ed. Fernando Nery, o discurso de 30 de juiho

4) Moreno Brandão - Rui Barbosa, mestre do vernáculo - 53 " segso Rui - Queda do Império, 1921, tomo I - LXXXI - in "Obras Completas"

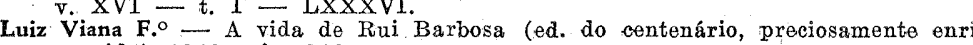

5) Rui Q Discurso proferido no Instituto dos Adrogados, 1911, pág. 7.

Marck, cit. por Rui.)

à "Mocidade è exhio", 1934, pág. 11

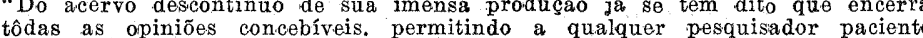
encontrar o trecho favorável ou infenso à idéia para expor. A acusação v. carta de Rui a Pinheiro Machado, 1905, in Luiz Viana F.o - "A vida de. Rui Barbosa", 3. à ed., pág. 311

8) Rui = Finanças $\theta$ política. 154.

in "Comentários à Constituicąa
por Homero Pires, II, 339, 340. 
- mal, da verdade para o êrro. Quando, pelo contrário, vão do êrro para a verdade, ou do mal para o bem, não são contradiçóes, mas re formas, não lhe merecem ferrêtes, senão louvores." "9)

Para se apurar o pensamento de Rui a respeito dos sistemas presidencial e parlamentar de govêrno e sua aplicabilidade ao nosso país. o inventário dos textos e a perquirição das idéias se fará de preferência em escritos políticos. Os seus trabalhos jurídicos são de advogado. Conduzia, de ordinário, todos os recursos para a solução exata de um caso concreto, prèviamente enterreirado dentro dos quadros do direito positivo, ainda costumasse dar às alegações um desenvolvimento, um lustre e uma informação inigualáveis. ${ }^{10}$ )

Mas ainda nos documentos políticos não será fácil a colheita. Em: Rui predominou o doutrinador político sôbre o pensador tranqüilo e distanciado da arena dos combates. Mesmo em seu livro mais impes. soal não conseguiu forrar-se ao duelo quase forense em que eram partes o exilado e o florianismo. ${ }^{11}$ )

\section{A REPÚBLICA E 0 REGIME PRESIDENCIAL}

Monarquista em 89, através da sua propaganda pela federação. achegou-se aos arraiais republicanos, ofuscando-lhes em brilho, vigor oposicionista e popularidade, e através dela, em 15 de novembro, entrava no govêrno provisório. ${ }^{12}$ )

Radicalmente avêsso à centralização tradicional, após 13 de maio. advogava como salvadora da monarquia a reforma federativa e aos. embargantes dela denunciava a solução republicana como corolário îr. recusável e fatal. ${ }^{13}$ )

\footnotetext{
9) Rui - Contra o militarismo - 1. série, 60. "Fstoss a. Calúnia", 1931 pás, em

1) cf. cf. Rubem Nogueira - "O advogado Rui Barbosa", 1949, págs. 26 a 30.

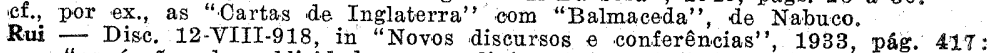

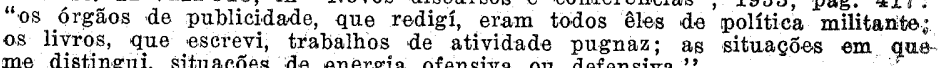

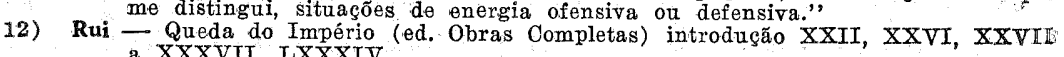
Anais do Congresso Constituinte dá República, 1924, 1.0 vol., pág. 618 Obras Completas - v. XIX, t. I, 265. - (Discursos parlamentares). Oracōes do Apóstolo - 1923 pas.

13) Rui - Cartas de Inglaterra monàrquia para a república. 112, 114

Queda do Império in introd. págs. indicadas sob o n.o 12

Discursos es eonterênicias - $287,8$.
J. Nabuco - Discursos parlamentares
$-372,3$.
}

E não tendo optado pela república senão às suas vésperas, não The traçara um plano de organização, mesmo porque, não fôsse a in: terferência militar, a despeito de ser uma idéia em progresso, náo atingiria ela pròximamamente o poder. A república resultou de um acidente, não foi um movimento nacional. ${ }^{14}$ ) Os vitoriosos de $15 \mathrm{de}$ no. vembro foram colhidos despreparados para as tarefas de govêrno.

Na primeira semana de administração republicana, um único cérebro pensou e agiu - o de Rui. ${ }^{15}$ )

Ao demais, a propaganda se fizera numa base negativa ${ }^{16}$ ), contra a coroa e contra o unitarismo. Nem Rui, liberal independente, nem os pregoeiros do novo credo, haviam deduzido seu pensamento relativamente ao regime de govêrno. ${ }^{17}$ ) Federação e república eram as vozes aglutinadoras do terceiro partido, fôssem, ao tempo, abolicionistas ou não... 18) Foi pelo caminho da primeira, embaraçado pelos governantes da época, que Rui, desejoso da "federalização das províncias, sob a presidência parlamentar da monarquia" ${ }^{19}$ ), atingiu a república.

Em matéria de reivindicaç̃es liberais, se é certo que não sobreexcederam os republicanos à ala que tivera em Tavares Bastos seu predecessor, em relação ao regime de govêrno não se verificou propaganda do sistema americano. ${ }^{20}$ )

Mas, proclamada a nova forma de govêrno e realizada a reforma federativa, soara o momento de vestir jurìdicamente a ordem estabelecidá pelos sucessos. E não tardou o govêrno provisório em nomear uma Comissão de juristas para a elaboração de um projeto constitucional ${ }^{21}$ ), que, vencidas as divergências, ${ }^{22}$ ) apresentava um, revisto, discutido, aprimorado e enriquecido pelo ministério republicano, através do titular da pasta da Fazenda.

14) Rui - prefácio ao livro "O abolicionismo", de Duque Estrada

Excursão eleitoral ao Estado de São Paulo, 191.

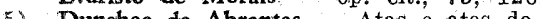

do govêrno provisório - pág. 30.

atista Pereira - Rui, o estadista da República, - 1943 - 41 o seg

16) Medeiros. e Albuquerque - - Parlamentarismo e presidencialismo no Brasil, 1932 oliveiras. 12 e segs. até 26 . 0 iana 1922 , págs. $78,9$.

1.7) Rui - Carta a Dantas - in João Mangabeira, op. cit., 35, 6 . Queda do Império - passagens cit. sob n.o 12 e pág. XXV.

18) José Maria dos Santos - A politica geral do Brasil - 1930, págs. 207 a 212

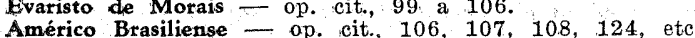

19) Rui - Queda do Império - introd, XXVII.

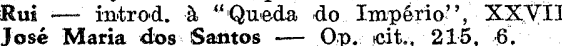

José Maria dos Santos - Op. pit o, 215,6 .

José Augusto - Diário do Congresso Nacional, 17-V-49, pág. 3967

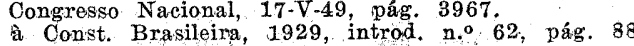

22) Maximiliano - op. cit., pág. 88. 
Tão avassaladora e absorvente foi a contribuição de Rui, que poderia redizer mais tarde, e repetidas vêzes, que a Carta de 24 de fevereiro era principalmente obra sua, tanto acrescera ao antigo projeto da comissão presidida pelo velho Saldanha Marinho. ${ }^{23}$ )

Mas parece que só depois de ultimado o trabalho dos juristas, encetou Rui a sua ação construtiva na feitura do Diploma republicano, se descontado o decreto n. 1 , de 15 de novembro, no que êle encerra de prenúncio àquela lei magna.

Figurando já o sistema presidencial no projeto da Comissão dos Cinco, não é de presumir-se se filie a escolha do estranho molde à influência de Rui. ${ }^{24}$ )

$\mathrm{O}$ que é certo, porém, é que o relator, o vogal do ministério junto ao chefe do govêrno, aceitou e perfilhou a inovação e, à luz da experiência americana então centenária, completou-a e aperfeiçoou-a. Se a repelisse, se a impugnasse, dada a sua ascendência indiscutível e indiscutível superioridade sôbre os seus pares e sôbre Deodoro, possivelmente não teria passado o presidencialismo de um a outro projeto $\mathrm{e}$ dêstes ao texto promulgado em 24 de fevereiro. ${ }^{25}$ )

Talvez haja assim exagêro na assertiva de que tenha sido Rui "o transplantador do presidencialismo para o Brasil," 26) adotado sem propaganda, sem debate e na ignorância de suas peculiaridades ${ }^{27}$ )

A tendência à imitação, a fôrça da inércia para aprovar o que era oferecido pelos antigos propagandistas, o amor à novidade, a desorien-

23) Rui - Finanças e política - 129

Oracão do apóstolo - $129^{\circ}$ "o pireito" - XOII - 55

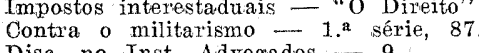

Novos discursos e conferências - 416.

0 art. $6 .^{\circ}$ da Constituição - 1920,15 . ${ }_{2 .}^{a}$ ed., 394,5 .

Homero Pires - introd, aos "Comentários" - XII - XIII - XXIX.

Pedro Calmon - pref. ao v. XVII - t. I das "Obras Completas"; XI e XII.

24) B. os diversos textos, in "Obras Completas" - v. XVII, t. I (A Constituiçấ de. 1891), mais o prefácio ao mesmo tomo de Pedro Calmon.

v. Viana F.o - op. cit., 218 e 219. "Ainda uma vez seria êle (Rui) o relator. o redator, e, afinal, o verdadeiro autor da futura Constituicãa. Aliás, nem por Saldanha Marinho. Nem mesmo a quietude de Petrópolis, onde instalara, fugindo às inclemências do verão, lograra suavisar-lhe os debates.

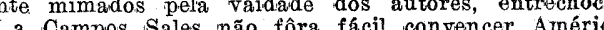
Brasiliense, republicano "cheio de "servicos à causa comum, da conveniêncici de abrir mão das suas idéias parlamentaristas."

25) Joáo Mangabeira - op. cit., págs. 41 e segs.

Vianna F. - op. cit., 2.11 .

Max Leclerc - Lettres du Brésil, 1890, pág. 126

(10

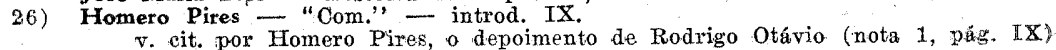

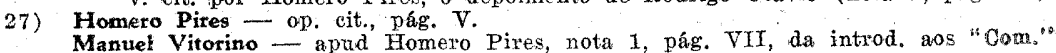

tação mental típica das quadras revolucionárias, em que as palavras se sobrepõem às idéias, $e$, repetidas, acabam por dominar sem contras te, ${ }^{28}$ ) a identificação, sem restrições, com a nova ordem, dos adventí. cios do regime adotado, a posição defensiva dêste em face do número e do valor dos antigos servidores de coroa, a assimilação das formas republicanas de govêrno e federativa de Estado com o sistema presidencial vigente nos Estados Únidos e a do sistema parlamentar com a mo. narquia centralizada, explicam a quase unanimidade das decisões, neste particular, do Congresso eleito sob a vigência do Regulamento Alvim. ${ }^{29}$ )

Promulgada a Constituição, estremecendo pela sua pureza e pelo seu decente cumprimento, inicia Rui, numa luta campal com o autoritarismo, as medidas de exceção, os sofismas de secretaria, uma verda. deira lição de coisas para o povo, os políticos, os advogados, o Supremo Tribunal..., pois as novas instituições acolhidas o foram ao arrepio dos antecedentes parlamentares do país, não tinham raízes nos componentes históricos da nação. ${ }^{30}$ )

Ele mesmo, embora durante a campanha federalista estudasse alguns aspectos da vida jurídico-política americana, escreveria a Joaquim Nabuco, em 1906, que "a minha admiração da maravilhosa República norte-americana precedeu a minha admiração para com a In. glaterra, na qual depois se absorveram as minhas tendências e os meus estudos. Com a nossa revolução de 89 êles voltaram aos Estados Unidos." ${ }^{31}$ )

\footnotetext{
Clóvis Beviláqua - Juristas Filósofos - 22 .

Rui - Discurso a "Comentários"). Medeiros e Albuquerque - op. cit., 12, 19, 20, 21.

28)

Assis Brasil - Do govêrno op. "cito., 23 a 26.

- Cartas de Inglaterra - pref, 130 rep. brasileira - $1934-25$ a 28

Ta Sales "Cartas da Europra - apud Lúcio de Mendonęa - pref. XXX da Rússia ou o regime presidencial: aquêle para as monarquias. se o quí.

Maximiliano êste para a República."

que se conheceu no Brasil,; ${ }^{\circ}$ mais engenhoso aparelho de fraude eleitoral Afonso Celso - Década Republicana - II, 224.

Raul Pilla

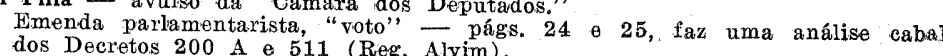
dos Decretos 200 A e 511 (Reg. Alvim).

v. Anrais do Congresso Constituinte, 3 vs. as raras divergêneias de C. Zam

Nogueira Oliveira Pinto ( 1,1091$)$, Rosa e Silva, Frederico Borges, Almeida

v. "Agenor de Roure -A Constituinte republieana - 1.0 vol,, 346.

30) Rui - "Comentários" - I, pags. V \& VI.

31) Carletons Sprague Smith - "Os livros norte-amerioanos no pensamento de Rui
} 


\section{PRESIDENCIALISTA OSTENSIVO}

O certo é, porém, que nos primórdios da República ostensiva é a posição de Rui em favor do sistema presidencial.

Em 1892, acorde com a opinião reinante, associava o sistema com a forma de govêrno e proclamava em ásperos acentos: "renunciar ao federalismo é emascular-se. Desistir do fôro republicano é prostituirse. Da federação não se retrocede para a centralização. Da América presidencial não se volve para a realeza ultramarina."

E apontando o parlamentarismo e o militarismo como os dois inimigos capitais da República, concluía que os agravos carregados à conta do regime republicano ou do sistema presidencial não passavam de uma projeção da diátese monárquica. ${ }^{32}$ )

$\mathrm{E}$ antes dêsse discurso proferido na Baía já despido do mandato legislativo, ao Senado expandia-se em louvores à Constituição que competia "com a mais maravilhosa das organizaçóes republicanas, a dos Estados Unidos, em princípios liberais, em expansão democrática, em instituições federalistas." ${ }^{33}$ )

E logo após, ao despojar-se da cadeira senatorial, no último capítulo do "Manifesto à nação", revoltava-se por ver "em vez da forma presidencial, do regime americano, uma híbrida procreação da ditadura com o parlamentarismo..." $" 34$ )

E em 95, numa passagem de "Duas glórias da humanidade", na opção procedida em favor do regime americano, embora indicasse havê-la feito por exclusão, não se mostrava menos incisivo: "para lhe dar (à Constituição) feição liberal, a constituição dos Estados Unidos era o modêlo, que se nos impunha. Fora dela só teríamos a democracia helvética, intransplantável para estados vastos, e os ensaios efêmeros da França, tipo infeliz, além de oposto às condiçóes de um país naturalmente federativo como o nosso."

E noutra carta, $n^{\text {" } O}$ Congresso e a Justiça no regime federal", confessaria que "se estivesse nas mãos de uma revolução converter a realeza pessoal dos Braganças na monarquia parlamentar da casa de Hannover, eu, em 15 de novembro, teria proposto a troca de Pedro II pela rainha Vitória... Privado, porém, de realizar êsse prodígio, obrigado a escolher para a república inevitável a mais satisfatória das for. mas..." 35 )

\footnotetext{
32) Rui " "Discursos e conferências" - $312,319,309$ è 310 .

33) Rui "A "Baia a Rui Barbosa" = 20 "Finangas e política" 283 .

34) Rui - "Finangas e

34) Rui 二 idem - Carta de Ingia

relativamente ao "poder pessoal" "c. "Com." - III, 312 e 320 (Discarso

"Uma campanhá política" ${ }^{\text {ao }}$ Senado, $192-$ cit. sob n.o 127
}

\section{POSIÇÃO CRÍTICA}

E daí uma posição crítica vai dominando o espírito de Rui, que já em 92, na memorável petição de habeas-corpus, acentuava ao Supremo Tribunal que, consoante o lado para onde pendesse ao decidir a espécie, êle revelaria "se entramos realmente, pelo pacto de 24 de fevereiro de 1891, no domínio de uma constituição republicana, ou se essa exterioridade apenas mascara a onipotência da mais dura tirania militar", sob a qual "o país está virtualmente convertido numa praça de guerra, a liberdade, para os cidadãos brasileiros não fica sendo mais que uma esmola precária da fôrça, e a revolução de 15 de novembro, mãe das novas instituições, mãe dêste tribunal, não terá servido senão de transferir para nós o cativeiro, de que em 13 de maio emancipamos os escravos." ${ }^{36}$ )

No ano imediato, na campanha jornalística "com a lei, pela lei e dentro da lei" ${ }^{37}$ ), ponderava: "O presidencialismo americano sem a responsabilidade presidencial, porém, é a ditadura canonizada com a sagração constitucional. Basta a eliminação dêste corretivo, para que todo êsse mecanismo aparente de freios e garantias se converta em mentira." 38 )

E de volta do exílio, agradecendo a homenagem que o "Jornal do Comércio" rendia ao autor das "Cartas de Inglaterra", voltaria à tese que, exposta na primeira petição de habeas-corpus, sustentaria repetidamente até o discurso de posse na presidência do Instituto dos Advogados, e que junto com a anteriormente referida, passaram a constituir as duas condiçôes sem as quais o regime americano seria o mais detestável dos métodos de govêrno.

Orava êle: "Os decretos da administração, as leis do Congresso seriam citados perante êles (os Tribunais) e por êles acareados com o direito constitucional. Envolvido no manto dêste e apoiado na autoridade dos juízes, o indivíduo inerme lutaria vitoriosamente contra a vontade das maiorias e o arbítrio das ditaduras administrativas. Esta feicão, a mais bela do regime americano, imprime-lhe, acima de tudo, um caráter fundamentalmente jurídico. Mas também se êsse caráter se anula, o regime americano degenera no mais detestável dos governos." 39 )

Da tribuna da imprensa, por onde se acostumara a conversar com os seus compatriotas "na mesma plenitude de franqueza com que me" dirigisse para dentro de mim mesmo" ${ }^{40}$ ), em 98, registrava que "na

36) Rui 二 o Estado de sítio — Rio, 1892, págs. 6 e 7.

38) Rui = "Comentários" - III, 433, 4. (Jornal do Brasil, 26-V-893): Obras

39) Rui = "Oracos do apóstolo", - 123.

13 - R. F. D 
forma política onde se moldou a Constituição brasileira, todos os grandes pensadores, todos os observadores de valor são unânimes em reconhecer e temer o poderio dos Presidentes. Dos freios e contrapesos, a que o regime parlamentar submete a coroa dos Monarcas, a República Presidencial exonerou a autoridade do Chefe do Poder Executivo. Todo êste ramo da energia constitucional absorve-se numa só individualidade, sôbre a qual nenhuma ação têm os Ministros e o Congresso. Em vez de ser governado por uma Comissão do Parlamento, o país é regido pela discrição de um homem, cuja fôrça igualaria a do Tzar, ou do Sultão, se o curto período do seu ascendente o não desarmasse, a des. centralização federativa o não circunscrevesse, e o papel extraordinário da Justiça Federal lhe não criasse obstáculos à ditadura." ${ }^{41}$ )

E da tribuna da imprensa passa à do Senado para, no mesmo mês advertir que "se há uma coisa a estranhar na nossa história política, pelo menos, é esta a impressão causada no meu espírito, é que se há um poder forte, um poder onipotente, cujo pedido de faculdades não se possa tomar ao sério, um poder que só carece de ser limitado, contra o qual os direitos constitucionais têm necessidade de se rodear de novas garantias, é o Poder Executivo." "42)

Um ano depois, na sua "Imprensa", "órgão retilíneo e inflexível do direito" ${ }^{43}$ ), cauteriza as formas do novo regime nestas palavras formalmente condenatórias, que nem passaram despercebidas aos monarquistas, interessados em lançar contra a república aquilo que, se decorria do que efetivamente surgira com ela, dela não era mais que atributo acidental e dissociável:

"Entre nós a êsse respeito, dizia em referência às Câmaras, da Monarquia para a República a decadência foi considerável."

$\mathrm{E}$, verificando que a corrente histórico-social do país não sofrera alteração, raciocinava: " $\mathrm{E}$ ' a mesma linfa, o mesmo leito, o mesmo volume. Apenas se modificaram as formas constitucionais." 44 ) E no Senado, ao discutir a lei orçamentária, profligava: "Não venho discutir nem formular emendas. Emendar ou discutir seria violar a senha da época. A senha da época é votar. Há quatro ou cinco anos que o senado não faz, que the não deixam o direito de fazer outra coisa no exercício da sua função suprema... Hoje especialmente em matéria financeira, neste regime, qual o tem feito a nossa vocação admirável para êle, o senado tem a honra de não ser mais do que o grande carimbo do presidente da república... Bem haja esta nossa resignação, esta serenidade nossa. Graças a elas, desfruta o senado a bem-aventurança atual

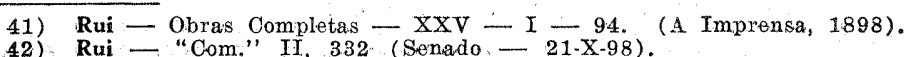

42) Rui 二 "Com." II, 332 (Senado-21.X-98). 189

43) Rui - "A Imprensa"

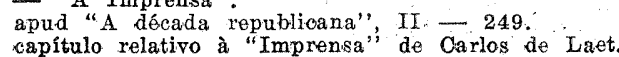

da sua inutilidade e pode gabar-se de que se acha virtualmente abolido. Consolidem-se êstes bons costumes, e teremos então resolvido o problema da pedra filosofal em matéria de formas constitucionais, firmando uma república, onde o govêrno seja exercido exclusivamente por uma Câmara ao aceno do chefe do poder executivo." 45)

Dir-se-ia que Rui rejeitava definitivamente o grosseiro mecanismo de govêrno, "as formas constitucionais" adotadas com a república, sempre esquiva aos decantados freios e contrapesos do regime, com a exoneração da responsabilidade de ambos os poderes políticos, as Câmaras amesquinhadas a um locutório sem reflexo no traçado da política geral do país.

Ainda acreditava, porém, na possibilidade, e pregava a necessidade de uma aplicação honesta da Lei Suprema. Tanto podem no homem as suas obras, quando por elas se estremece através das "afinidades morais da paternidade", postas à prova até no exílio. ${ }^{46}$ )

O regime republicano, como vinha sendo praticado, não se avan tajava ao imperial, mas Rodrigues Alves tentaria a "recomposição material do território e a recomposição moral do regime ${ }^{47}$ ), e Rui, envelhecido na experiência dos costumes e dos homens políticos, desencantado de ilusões estéreis, disposto a dobrar-se às transações necessárias ${ }^{48}$ ); resolve "tentar o outro caminho, menos fácil, menos simpático, menos aplaudido, menos brilhante: de ver se lograria auxiliar um pouco a obra dos governos com o apoio da sua (desta minha) têmpera, da sua (minha) educação jurídica e liberal, tão longamente posta ao serviço das oposições." Dispusera-se a trocar "a popularidade pela responsabilidade." 49 )

Não obstante, tais intenções ditadas na fase construtiva da República não embaraçavam fôsse comunicando ao Senado o resultado dos seus estudos.

"Os Estados Unidos, nos tempos organizados e calmos, urava êle em 903, são o despotismo exercido por seis indivíduos: o Presidente da República, o Secretário do Estado, o Secretário do Tesouro, o Presidente da Câmara dos Deputados e os dois Presidentes das duas Comissões de Finanças... Estes seis indivíduos são os árbitros da política americana, são os membros, na linguagem dêstes escritores, dêste absolutismo irresponsável, ao qual obedece a política dos Estados Unidos, nos tempos ordinários e calmos." ${ }^{50}$ )

45) Rui - Discurso ao Senado, 9-XI-899. 249 e

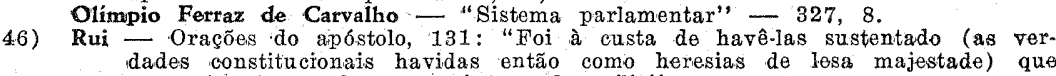
"comprei a honra da perseguiçãa e do exílio".

48) Rui = Oarta a Pinheiro Machado, apud Viana F.o - op. eit., 311.

49)
50) 
Mas a transação não se converteria em oportunismo, nem se demoraria o apoio daquela têmpera liberal, quando "a política republicana continuava (continua) a ser um simples jôgo de nomes próprios" e o exercício do poder "o único instrumento eficaz para o bem nesta terra." ${ }^{51}$ )

As novas "formas constitucionais" haviam restabelecido um poder pessoal em proporções inauditas ao tempo do segundo reinado e só equiparáveis ao em que "o primeiro imperador dispunha das liberdades nacionais" ${ }^{52}$ ) e o govêrno de gabinete não medrara ainda à margem da Carta outorgada. ${ }^{53}$ )

Mas o poder pessoal, de que se fizera "tenaz adversário" sob o Império, decorria da total independência do govêrno em face da representação popular, da conjugação na mesma pessoa dos papéis de chefe do Estado e chefe do govêrno, da libertâção prática dos reflexos de opinião do eleitorado desde o sufrágio, da fixidez dos mandatos, da República cesarizada pelo presidencialismo.

\section{PROPOSITURA DA QUESTÃO}

A campanha civilista vai inaugurar uma fase no pensamento jurídico-político de Rui, relativamente ao regime de govêrno. $O$ desfecho do período civil da República, consolidada e liberta das irritaçóes revolucionárias, trecho de bonança e progresso, denunciava a rigidez e o artificialismo das novas "formas constitucionais". A comunhão, num só indivíduo, das funções de primeiro magistrado e dirigente da administração, funções diferentes e às vêzes contraditórias, acaba por excluir a figura do magistrado, na qual Nabuco ${ }^{54}$ ) via uma necessidade da América do Sul, mas que é comum a todos os grupos humanos. Daí o aparecimento de uma outra fôrça, de um outro poder", em contraste aos dispositivos básicos que dela não cogitam senão para proclamá-la defensora da pátria e garantia dos poderes constitucionais, da lei e da ordem, "poder" inepto a fazê-lo, mas que tenta, por vêzes, restabelecer a harmonia social, deslocando o eixo da política, como registrou em frase equívoca, em 1909, o velho redator do primeiro Manifesto republicano - o poder do quartel.

51) Rui - Carta a José Marcelino - in Viana F.o - op. cito, 325, 326

"Com." III, 320.

53) Joaquim Nabuco - Ứm estadista do Império, 1936, I, 51

Afonso Celso - Oito anos de parlamento -289 a

osé Maria dos Santos - op. cit. (êste 6 o tema central do lirro).

Olimpio Ferraz de Carvalho - op. cit., idem. Otavio Tarquinio

Luiz Delgado - op. cit., 9.

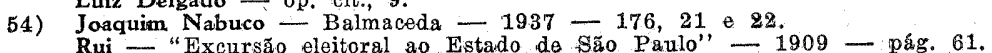

$\mathrm{Na}$ qualidade de candidato à presidência da República, pela primeira vez Rui vai equacionar a problema do sistema de govêrno, e embora o resolva pelo simples aperfeiçoamento do vigente, reconhece que "a natureza democrática das nossas instituições nada perderia com a substituição do govêrno presidencial pelo govêrno de gabinete", explanando ainda, em sequência, que no confronto entre um e outro tipo "as formas parlamentares levariam a melhor; porque mais vale, no govêrno, a instabilidade que a irresponsabilidade." 55 )

Como se vê, prendiam ainda o "mártir da convenção" de 22 de agôsto, os vínculos das "afinidades morais da paternidade" constitucional, renovados em cada defesa contra os sofismas, êle que era "um mestre-escola, um pregador, um mártir dessa Constituição." ${ }^{56}$ )

$\mathrm{E}^{\prime}$ que a evolução do pensamento de Rui, no aspecto que vem sendo focado, se operou não só numa gradação lenta, mas também vencendo como que uma resistência, originária da sua solidariedade intelectual ao Código de 91, visto sempre no conjunto de seus elementos constitutivos ou dos que benèficamente enxertara no processo constitucional brasileiro.

Mas Rui, que se limitara até então a criticar o presidencialismo, em 910, ainda que opusesse dificuldades em conciliar o govêrno de gabinete com o Estado federativo, idéia antiga e não original ${ }^{57}$ ), problematizou o debate, antecipando-se "aos breves anos" em que "se venha a impor a sua discussão." 58)

Embora reconhecesse porém, a superioridade, pelo menos teórica, do parlamentarismo, regime que Campos Sales imaginava ser inerente à monarquia, não propugnava ainda a sua adoção.

$E$ essa atitude no momento era lógica e política - no melhor sentido - ainda que deixasse expresso que "a ausência de responsabilidade (que), reduzida nas instituiçóes americanas ao "impeachment" do chefe da nação, não passa de uma ameaça desprezada e pràticamente inverificável", quando já sentenciara que "o presidencialismo americano sem a responsabilidade presidencial, é a ditadura canonizada com a sagração constitucional." 59 )

Extremar-se em propor a mudança do sistema de relaçôes entre os poderes políticos, a par de outros retoques reputados de visível oportunidade, abrindo com "ela o primeiro ensaio de reforma constitucional, seria expô-la, quase com certeza, ao malôgro, em tópicos

55) Rui - Excursão eleitoral aos Estados da Baía e Minas Gerais - 1910 -

56) Rui - Contra o militarismo - 1.a série, 87.

7) Rui = Cartas de Inglaterra $=291$.

58) Rui - op. cit. sob n.o 55 supra, pág. 25.
59) Rui - op. cit. supra -26 e.

"Com." cit. supra - 26 e. 434 (Jornal do Brasil, 26-V-893)

"Com," III, 434 (Jornal do Brasil, 26-V-893). 1893 ). 
a respeito dos quais era (é) exeqüível, por açodamento em relação a um problema ainda não maduro, contra o qual as exigências da ortodoxia republicana eram (são até agora) irredutíveis." 60)

Depois, o candidato tinha o apôio de algumas dessas correntes "da ortodoxia republicana" ${ }^{61}$ ) e a tarefa revisionista não constituía o objeto capital do civilismo. Acoimado de partidário da reforma, em contraste aos seus adversários que se assoalhavam conservadores, Rui aceitou o plano em que se colocava a disputa, que, aliás, se conciliava com seu distante passado, ${ }^{62}$ ) mas o movimento civilista nasceu se opondo à deturpação do regime: à intervenção do presidente na escolha do seu sucessor, ao caucus legislativo, à política dos governadores, à fraude eleitoral... ${ }^{63}$ )

Assim, se como pensador não concluíra pela necessidade do regime parlamentar, como solucão decente a um dos nossos problemas políticos, como candidato não deveria mesmo chegar a uma fórmula radical, pois se é certo que o político autêntico deve orientar e educar o povo - e quantas renúncias de Rui não tiveram êsse sentido! - sementando-o de idéias novas, um candidato à presidência da República, que não é um representante, tratando-se de eleição singular, ajusta-se mais à conceituação de Bagehot do estadista democrático, "um homem pouco corrente dotado de opinióes correntes", mais deve refletir expondo, do que inovar propondo. ${ }^{64}$ )

Demais, é de aduzir-se que, relativamente às "formas constitu" cionais", guardava Rui ainda posição semelhante à que mantivera em relação à forma de govêrno. No prefácio às "Cartas de Inglaterra" esclarecera que "o interêsse do país não está em ser governado consoante a fórmula dêste ou daquele sistema (monárquico ou republicano), senão sim em ser bem governado; e os governos bons são os temperados e fiscalizados pela discussão", e em plena campanha civilista confessava que "a República é uma forma. A substância está na liberdade." ${ }^{65}$ )

Transcorrida, porém, a fase áurea daquela República, a que re-

60) Rui - op. cit. sob n.o 55, pág. 25. João Moderá ser senão o revisionism

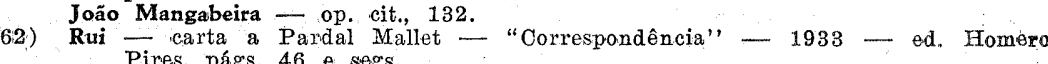
Pires, págs. 46 e segs.

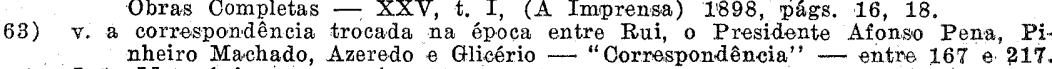
foáo Mangabeira - op. cit., 117 a 123 .

64) Raul Pilla F- "Exegese de um preconceito" — artigo publicado no "Diário de

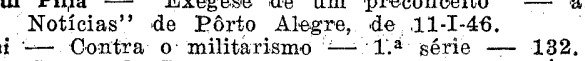

65) Rui - Contra o militarismo - 1.: série - 132 Queda do Império - introd: - XXVII

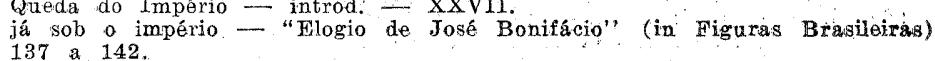

cusaria, em breve, sentir preferência, "como se República daquela (desta) natureza merecesse a predileção de alguém" 66) que tivesse uma têmpera liberal e uma formação jurídica, e cujo mecanismo perro e artificioso mesmo os presidentes mais austeros; honestos e empreendedores se revelaram incapazes de superar, Rui começa a articular o seu libelo acusatório contra o sistema presidencial, contra o regime que seria o mais detestável de quantos existissem, o do absolutismo irresponsável, se falhasse o impeachment como apurador da respon. sabilidade presidencial ou os pretórios não se tornassem o abrigo, à semelhança dos velhos templos, dos direitos individuais.

\section{ARTICULAÇÃO DO LIBELO}

Logo em 1911, à face do Senado, testificava categórico: "neste regime, não há senão mentira, mentira e mentira! Mentem as leis, mente a Constituição, mente o Govêrno, mente o Congresso, tudo mente!" 67 )

$E^{\prime}$ que o regime presidencial é um processo de govêrno codificado e ossificado numa época em que eram mínimas as funçôes da administração, e resultou de uma conciliação que visava solucionar um problema nacional, em pleno século XVIII; não suporta assim a complexidade e o ritmo da vida moderna, exceto em seu país de origem, onde, aliás, os costumes desprenderam-se das fórmulas legais, sendo um regime que seguidamente se estilha frente à resistência dos fatos, em ditaduras mais ou menos ostensivas e em revoluçóes mais ou menos pronunciadas. ${ }^{68}$ )

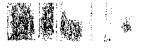

\section{A IRRESPONSABILIDADE}

Da responsabilidade presidencial, sem o que o regime americano seria "a ditadura canonizada com a sagração constitucional". já asseverara - "reduzida, nas instituições americanas, ao impeachment do chefe da nação, não passa de uma ameaça desprezada e pràticamente inverificável", ${ }^{69}$ ) e em 1913, após registrar as inúteis tentativas de 66) Rui - aparte dado a Pinheiro Machado, in "Pinheiro Machado, Discursos prosatélite e a intervenção no Estado do Rio" - 1915 - pág. 48.

68). Rui - "O Direito do Amazonas ao Acre Setentrional", 1910, I, pagg, 69 o segs, "... a constituição americana ora em vigor seja, em grande parte, obra

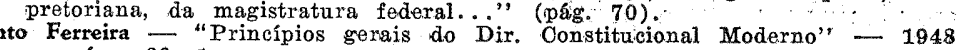
- págs. 60 , 1.

Nabuco - Balmaceda - 49

Anais da Assembléia Constituinte, 1946, III, 56 e 57 . v. apartes do dep.

Rui Agamenon Magalhães ao discurso do dep. Raul Pilla

que a estabilidade, num sistema de govêrno, ê a qua duatilidade em so teforto do

69) Rui sem revoinções." 
responsabilizar o chefe do Estado, certificava na mais autêntica das certidóes: "daí em diante ninguém mais enxergou na responsabilidade certidóes: "daí em diante ninguém mal senão um tigre de palha. Não é sequer um canhão de museu, que se pudesse recolher, entre as antigualhas históricas, à seccão arqueológica de uma armaria. E' apenas um monstro de pagode, secção arqueologica medonho na carranca e nas garras imóveis." to );

um grifo oriental, medonho na carranca e nas garras imóveis.

Surpreendida em flagrante a irresponsabilidade congenita ao regime, será ela univel à lei, segundo a qual, "acima de tôdas as leis positivas sobranceia a primeira de tôdas as leis morais inerente à natureza das coisas: a lei que liga, inseparàvelmente, à ação a responsabilidade." ${ }^{71}$ )

$\mathrm{Na}$ mesma época condensava assim esta reflexão atroz aos seus deais: "hoje, a irresponsabilidade é o tecido mesmo do regime. Res: ponsáveis, debaixo dêle, só os homens bons, os inocentes, os amigos da lei, por guardarem a pureza dos seus sentimentos, terem a coragem das suas idéias, e não se meretriciarem nesse vasto lupanar, em que homens e instituições vão apodrecendo. Nada escapa dêsse exício geral. Tudo se vai, tudo se perde, tudo acaba. Tudo ruínas, ruínas e ruínas." 72 )

E no ano imediato, em 914, estudando a competência dos poderes políticos na decretação e suspensão do estado de sítio, asseverava res politicos tesouros da irresponsabilidade e onipotência dọ Presidente no regime brasileiro" cresceriam incomensuràvelmente se, decretado pelo executivo, não pudesse o Congresso, reunido, impedí-lo, suspendê-lo ou julgá-lo. ${ }^{73}$ )

\section{A FALENCIA DO IMPEACHMENT}

A verdade é que a falência do impeachment, processo apurador da responsabilidade no presidencialismo, não é originalidade da experiência brasileira. Sendo um processo de formas criminais, (ainda que não seja um procedimento penal estrito), repressivo, a posteriori, seu manejo é difícil, lento, corruptor e condicionado à prática de atos prèviamente capitulados como crimes. Seria punitivo, se lograsse ser plicado alguma vez, pois ainda pôsto em movimento, dificilmente chega a cumprir seu objetivo pela morosidade de fases que lhe é ineato daninho ao bem público.

70) Rui - Rúnas d eum govêrno - 1931 (ed. F. Nery) pág. 97.

70) Rui $\overline{0}$ Dínato do do Amazonas, II, 583 .

1) Rui - "Pensamentos" - coligidos por Moysés Horta, 1925, pág. 59 .

açáo. Trata-se de uma lei do mundo moral."

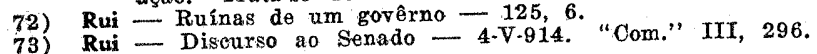

Fora do traçado da lei de responsabilidade, os atos e medidas de um governante, mesmo sejam nocivos aos interêsses gerais, uma vez não se enquadrem nas molduras da lei, inaplicável torna-se o "juízo político", inexistindo, de outra parte, recurso hábil, na estrutura do regime, para corrigí-los.

$\mathrm{Na}$ Inglaterra, desde o advento do regime parlamentar, o instituto, pelo seu primitivismo, pereceu. Perempto é na França. Nos Estados Unidos não passou de tentativa frustra; na Argentina é "uma instituição inútil" e no Chile "tem mais vida na literatura jurídica do que na realidade". Entre nós, se antes de estabelecido o parlamentarismo, com o seu específico equilíbrio de poderes, promoveram-se acusações a ministros, recurso que se estiolou à medida que a visão genial de Vasconcelos se objetivava nas praxes constitucionais, após a república, embora as tentativas se sucedessem, não passou de "um tigre de palha." "74)

Mas o próprio Rui, no ocaso do império, nas páginas fumegantes do "Diário de Notícias", não predissera que "o malôgro desta sanção penal no caso do presidente Johnson ficará, provàvelmente, constituindo lição terminante contra êsse meio de reprimir, no futuro, os delitos do chefe do Estado?" 75)

Boutmy fôra definitivo em seu julgamento: "é uma arma pesada e pouco manuseável, que, salvo caso de traição patente, só serve para dormir pendente da parede no museu das antigüidades constitucio. nais," 76 )

Êle mesmo já professara: "o impeachment, o julgamento político dos funcionários do Estado, pereceu na Inglaterra com o advento do govêrno parlamentar, desde que o gabinete, pelos fins do século dezoito, assumiu forma definitiva como a suprema autoridade execu tiva do Estado, representando, perante a Coroa anulada, uma comissão onipotente da Câmara dos Comuns. Sob êsse regime, o Soberano incapaz de fazer mal, porque não faz nada, justo é que seja inviolá vel, e os Ministros, que não podem contrariar o Parlamento, sem cair, pelo desapoio das maiorias, têm por julgamento político os votos parlamentares de desconfiança." 7.7 )

$\mathrm{E}^{\prime}$ que o regime parlamentar representa um estágio mais adian-

74) Rui - Novos discursos e e conferências - 351 .

Rotschaefer - On Constitutional law - 1939 . 10 á 113.

Rafael Raveau - Derecho Constitucional Chileno - 1939, pág. 222

Aurelino Leal - Teoria e pnatica da Constituição Federai par

Anibal Freire - Do podex executivo na república presidencial, 1916 - pág

Afonso Celso 1 . A Década Republicana - II, 207. Sôbre a acusaçắ dos mi

5) Rui - Queda do Império - Obras Completas - XVI - II - 310.

78) Boutmy - Estudos de Direito Constituciongl, trad L de Mendonca, pág. 81: "Oom." III Brasil - 43 - 2 -V-893.
Obras Completas - XX.-II-46, 7 . 
tado da democracia representativa, quando os governantes respondem efetivamente perante os deputados do povo, poder originário dela. 0 regime parlamentar, com o seu sistema de correlaçóes e conseqüente equilíbrio de poderes, supera o "conflito permanente organizado pela própria Constituição." " ${ }^{78}$ ) É-lhe inerente a responsabilidade polí. tica, medida preventiva e expedita, que, para se objetivar, não exige sequer uma infração por parte do govêrno, pois sendo tìpicamente um julgamento político, e aferindo ùnicamente a conveniência e o acêrto da política governamental, afasta a possibilidade dos erros chegarem ao extremo de ferir os dispositivos da lei de responsabili. dade, para só então ser pôsto em movimento aquêle canhão de cem to. neladas, na frase de Bryce. ${ }^{79}$ )

\section{FUNÇÕES DAS CÂMARAS}

Depois, "as cadeiras da Câmara e do Senado (já) não são, como no sistema parlamentar, os degraus para o govêrno do país, que o presidencialismo concentrou nas mãos do presidente da República; circunscrevendo estritamente os legisladores na função de legislar", ${ }^{80}$ ) e acarretou a nomeação do chefe do govêrno pelo sufrágio do povo ${ }^{81}$ ) por um prazo pré-fixado, seja ou não a capacidade adequada às circunstâncias, permaneçam estas ou se transformem no curso do período governativo, fato que inspirou Bagehot a sentenciar que "o êxito de uma loteria não é um argumento em favor das loterias." De outro lado, a funcão de legislar, que não é a única nem seria a mais importante do legislativo, pode realizar-se até em antagonismo com os desígnios do executivo, quando os poderes deviam marchar harmônicamente, como queria Montesquieu. ${ }^{82}$ )

\section{UMA SEMI-DITADURA}

Ao assumir a presidência do Instituto dos Advogados, em 914, depois de sublinhar que os excessos da administração e das maiorias le gislativas são dez vêzes mais arriscados e amiudados no regime americano do que sob o parlamentar, refere-se à suposta responsabilidade do executivo com o rigor destas expressões: "ninguém se acautela, se defende, se bate contra as ditaduras do Poder Executivo. Embora o Poder Executivo, no regime presidencial, já seja, de sua natureza, uma semi-ditadura... Para êste poder já existe uma lei de responsabilidade.

78) Boutmy - op. eit. sob n.o 7.6, pág. 81 ., trad. francesa, 1911, I, 314.

81) Rui - O Direito do Amazonas - II, 582.

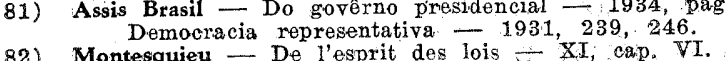

A Constituição a exigiu. A primeira legislatura do regime deu-se pressa em a elaborar. A medida tinha por objeto atalhar a degeneração da presidência numa ditadura permanente. Mas os nossos estadistas se contentaram de a estampar no Diário Oficial, e arquivá-la na coleção das leis. Raros são os seus artigos em que não hajam incorrido os nossos presidentes. Alguns a têm violado em quase todos... ainda não houve presidente, nesta democracia republicana, que respondesse por nenhum dos seus atos." E àinda: "A jurisprudência do Congresso Nacional está, pois, mostrando que a lei de responsabilidade, nos crimes do chefe do Poder Executivo, não se adotou senão para não se aplicar absolutamente nunca. Dêste feitio, o presidencialismo brasileiro não é senão a ditadura em estado crônico, a irresponsabilidade geral, a irresponsabilidade consolidada, a irresponsabilidade sistemática do Poder Executivo." 83)

Uma mentalidade que se educara no "trato usual do direito" e se afizera ao "hábito de seu estudo e à influência penetrante da sua assimilação" ${ }^{84}$ ), não permaneceria duradouramente fiel ao sistema que era mais do que uma semiditadura, mas uma ditadura em estado crônico, situação que se consuma porque o regime desconhece meios adequados a of erecer uma limitação equilibrada e eficaz entre os poderes, ignora os recursos para recompor o equilíbrio porventura desfeito entre êles, pois tendo ambos uma duração predeterminada, e desfazendose os laços entre representantes e representados realizada a operação eleitoral, apaga-se a possibilidade da "opinião pública pôr em movimento o parlamento e o parlamento, o gabinete" ${ }^{85}$ ), como, aliás, seria lógico num govêrno do povo pelo povo.

O que da suposta e intitulada independência dos poderes deriva é, ou a submissão de um, ou o conflito que a ambos paralisa, além da.in. coordenação na tarefa administrativa; "é a ataxia em matéria de administração, porque o órgão que delibera não influi diretamente no que executa, nem o que executa reage normalmente sôbre o que delibera, como exigiriam as leis fundamentais da organização." ${ }^{86}$ )

\section{ESTIOLAMENTO DA OPINIÃO}

A conseqüência de tal regime, arbitrário nas suas leis, artificioso no seu mecanismo, inflexível na sua dinâmica, arcaico na sua gênese, é o estiolamento da opiniáo pública, jarretada na sua influência sobe-

83) Rui - Novos discursos e conferências - 350 e 343.

85) W. Ivor Jennings - El regimen constitucional ingles - trad. esp. - 176.

86) Raul Pilla - "O regime politico e a administracấo pública", pág. - 5. (Câmars dos Deputados, sessão de 17 de setembro de 1947).
Raul Pilla - Anais da Assemblếia Constituinte, VI, 387, 8 ,

Clóvis Beviláqua - Linhas e perfís jurídicos - $85,86.8$.

Silva Marques - Direito Público e Constitucionạ - 1919, pág. 202, notá 
rana. 0 povo, "porque já não ouve, se desaveza de falar, para ao cabo, perder, também, a fala. No fim de contas se reduziu a uma pesada massa incônscia e surdo-muda; porque à fôrça de não escutar nada, se lhe gastou a oitiva e a linguagem, mergulhando-se-lhe a vida na surdez e na afasia", ${ }^{87}$ ) diria mais tarde, numa das suas campanhas memoráveis.

Mas o fenômeno ficou registrado no segundo discurso ao Instituto dos Advogados: "a opinião pública, mergulhada numa indiferença crescente, entregou-se de todo ao mais muçulmano dos fatalismos. Com o reinado sistemático e ostentoso da incompetência, cessaram todos os estímulos ao trabalho, ao mérito, e à honra." 88) E já anteriormente definira sua repulsa ao regime que "em vez de ser governado por uma Comissão do Parlamento, o país é regido pela discrição de um homem" e "sôbre o qual nenhuma ação têm os ministros e o Congresso", nesta frase tristemente verídica: "é uma confraria de irresponsáveis, governando, pela sua irresponsabilidade, uma nação insensível." 89)

E' fôrça concluir que um regime de govêrno irresponsável, mesmo derive de eleição popular, só muito remotamente será um govêrno democrático. Mais fácil é transformar-se, segundo a expressão corrente, numa ditadura a prazo fixo, pois se não há democracia sem eleição, pode haver eleição, sem democracia. ${ }^{90}$ )

\section{A CUSTÓDIA DOS TRIBUNAIS}

Extinta a responsabilidade presidencial, "absolutamente fictícia, irrealizável, mentirosa", ${ }^{91}$ ) só restava para salvar o regime de degenerar-se "no mais detestável dos governos; o despotismo sem os freios da tradição, o parlamentarismo sem $o$ ascendente das capacidades, a realeza sem a limitação das ambições, a burocracia sem a estabilidade adminitrativa, federalismo com os defeitos autoritários da centralização e a centralização com os vícios dispersivos do federalismo" ${ }^{22}$ ), zação e a centralização com os vícios dispersivos do federalis
só restava a custódia dos tribunais aos direitos do indivíduo.

E timbrando pelo mesmo diapasão, quatro lustros mais adiante, ao ser empossado na presidência do Instituto dos Advogados, exalçava assim a missão da Justiça: "o presidencialismo não tendo, como não tem, os freios e contrapesos do govêrno parlamentar, viria a dar na. mais tremenda forma do absolutismo, no absolutismo tumultuário e irresponsável das maiorias legislativas, das multidões anônimas e das

87) Rui - Campanha presidencial - 178.

88) Rui - Novos discursos e conferênêcias

a parlamentaris

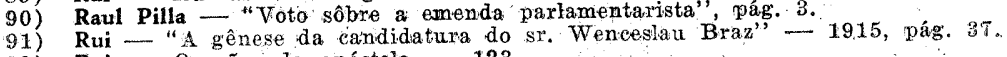

92) Rui - Oraçóes do apóstolo - 123. máquinas eleitorais, se os direitos supremos do indivíduo e da sociedadle, subtraídos pela Constituição ao alcance de agitações efêmeras, não tivessem na justiça o asilo de um santuário impenetrável."

E depois: "em todos os regimes livres, os poderes políticos têm freios e contrapesos à sua vontade, inclinada sempre a transpor as barreiras legais. Sob o govêrno de gabinete, êsses freios e contrapesos estão, quanto ao poder executivo, na responsabilidade ministerial, e, quanto às Câmaras legislativas, na dissolução do Parlamento. Com o govêrno presidencial, onde não existe nem o apêlo das maiorias parlamentares para a nação, nem a responsabilidade parlamentar dos ministros; a garantia da ordem constitucional, do equilíbrio constitucional, "da liberdade constitucional está nesse templo da justiça..." ${ }^{93}$ )

Mas, como a responsabilidade presidencial, falhara em tôda linha a interferência libertadora dos tribunais. A valia política da "mais bela instituição republicana" "num regime em que a toga é a única moderadora das paixões" ${ }^{94}$ ), o merecimento daquela condição apontada como regenerativa do sistema "de sua natureza uma semi-ditadura" foi apreciada no mesmo ano, em 914, quando ao Senado discorria sôbre "A gênese da candidatura do sr. W. Braz".

Dizia êle então: "os nossos governos nunca se acomodaram a êste freio da justiça, que é a característica do regime americano, criando um sistema de govêrno, em cujo movimento o mecanismo da responsabilidade dos altos funcionários do Estado se acha muito imperfeitamente garantido, criando um sistema de govêrno no qual a irresponsabilidade é, em última análise, a condição permanente dos dois poderes políticos da nação - o poder legislativo e o poder executivo. Quis o es* pírito judiciário dos nossos irmãos da América do Norte que num terceiro poder existisse uma barreira contra os excessos políticos, contra a onipotência das maiorias parlamentares, contra a tendência absorvente do poder executivo."

E em seqüência ponderava: "onde o govêrno se realiza pelo sistema parlamentar, o jôgo das mudanças ministeriais, dos votos de confiança, dos apelos à nação, mediante a dissolução das Câmaras, constitui uma garantia, já contra os excessos do poder executivo, já contra as demasias das maiorias parlamentares. Mas, neste regime, onde para o chefe do Estado não existe responsabilidade, porque a responsabilidade criada sob a forma do impeachment é absolutamente fictícia, irrealizável, mentirosa, e onde as maiorias parlamentares são manejadas por um sistema de eleição que as converte num meio de perpetuar o poder às oligarquias estabelecidas, o regime presidencial criou o mais chinês, o mais

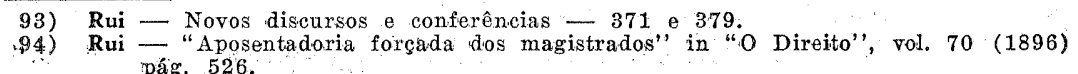


turco, o mais russo, o mais asiático, o mais africano de todos os regimes." 95)

Mas "a regra universal da justiça é sentenciar o direito controverso, e não pronunciar sôbre a conveniência da ocasião, ou o merecimento das partes." 96 )

Por isso não atua o judiciário sôbre os outros poderes; e porque resolve apenas os casos emergentes no curso dos pleitos, não exerce um poder de revisão das leis em abstrato e os efeitos dos seus julgados não se estendem além das espécies submetidas ao contraste judicial, que sòmente em relação a elas opera como oráculo definitivo. ${ }^{97}$ )

E, sem contar com a morosidade crônica dos pleitos que, em parte; inutiliza aquêle poder "até certa altura, político, exercido sob as formas judiciais," jamais será o recurso de que possa dispor o indiví duo, um remédio adequado a corrigir os erros políticos da administração e da legislatura. O campo natural destas é a discrição dentro das amplas linhas gerais que a Constituição lhes traça e "nada têm os tribunais com as questões de utilidade. Das questões de utilidade quem decide é a autoridade política." ${ }^{98}$ )

Os maiores erros poderão ser perpetrados sem que possam sequer ser submetidos ao crivo judicial. A questão política, que se formula em têrmos de conveniência ou utilidade, em regra é esquiva ao contraste judiciário, o qual sòmente se poderá exercer quando a questão, originàriamente política, entender também "com direitos de ordem in dividual." 99)

E operando a sentença entre partes, julgando os tribunais in casu, valerá como a atuacão da vontade concreta da lei fundamental, sobrepondo-se a uma ordinária ou a um ato administrativo - situação que se buscou corrigir atribuindo ao Senado o poder de "suspender a execução, no todo ou em parte, de lei ou decreto declarados inconstitucionais por decisão definitiva do Supremo Tribunal Federal."

Mas só onde o direito "se afirma, cessa a esfera do juízo político, entregue à administração, ou à legislatura, e começa o domínio judicial, onde se abstrai da estima pessoal dos litigantes, para não se considerar senão o valor impessoal dos seus direitos."

"Das questôes de utilidade quem decide é a autoridade política", e só ao direito cede a utilidade, ${ }^{100}$ ) consoante a lição clássica de Rui, tantas vêzes repetida e extraída aqui d"O Direito do Amazonas ao Acre Setentrional."

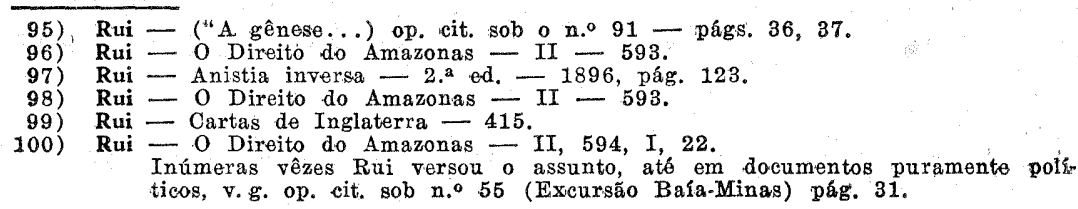

Em suma, o recurso do cidadão aos tribunais é predominanemente uma custódia individual, uma solução jurídica a um caso proposto em têrmos jurídicos. Só a responsabilidade política para ambos os poderes políticos, imanente ao regime parlamentar, é meio idôneo, apto, adequado a solucionar questóes políticas politicamente formuladas.

Mas nem é privilégio do regime americano possuir a justiça atribuiçôes de dizer da legalidade de atos administrativos ou da validade de leis. Verdade é que sem elas. "êste sistema é uma burla, uma falsificação, um estelionato, um roubo, é a mais indigna das formas de go. vêrno", como rugitava êle no Senado. ${ }^{101}$ )

A teoria é antiga, fôra esbocada no direito romano, explìcitamente definida e praticada explìcitamente no direito canônico, "advogada como aplicável sob a constituição imperial por espíritos da altura do de José Bonifácio na sua aureolada cadeira de professor" 102) e "na Europa, entre os países mais adiantados se ambiciona a criação de um. grande tribunal como êste, destinado a conhecer dos atos dos outros dois poderes políticos, mesmo quando se trata de países sob o regime parlamentar, o que quer dizer, onde existe responsabilidade para o go: vêrno", ${ }^{103}$ ) sistema existente na Noruega, já antes da remodelaçáo constitucional dos povos europeus, após o ciclone bélico que escorchou as velhas cartas. ${ }^{104}$ )

A teoria não se liga pròpriamene aos sistemas de govêrno. Será uma necessidade dos Estados federativos, de formas presidenciais ou parlamentares; é, porém, "um corolário comum a tôdas as constituiçóes escritas ${ }^{105}$ ) "a tôdas as constituições escritas com separação limitativa dos poderes," 106 isto é, rígidas, hieràrquicamente superiores à legiš lação ordinária. ${ }^{107}$ )

Mas "os nossos governos nunca se acomodaram a êste freio da jus. tiça", as vêzes que êle não falhou. ${ }^{108}$ )

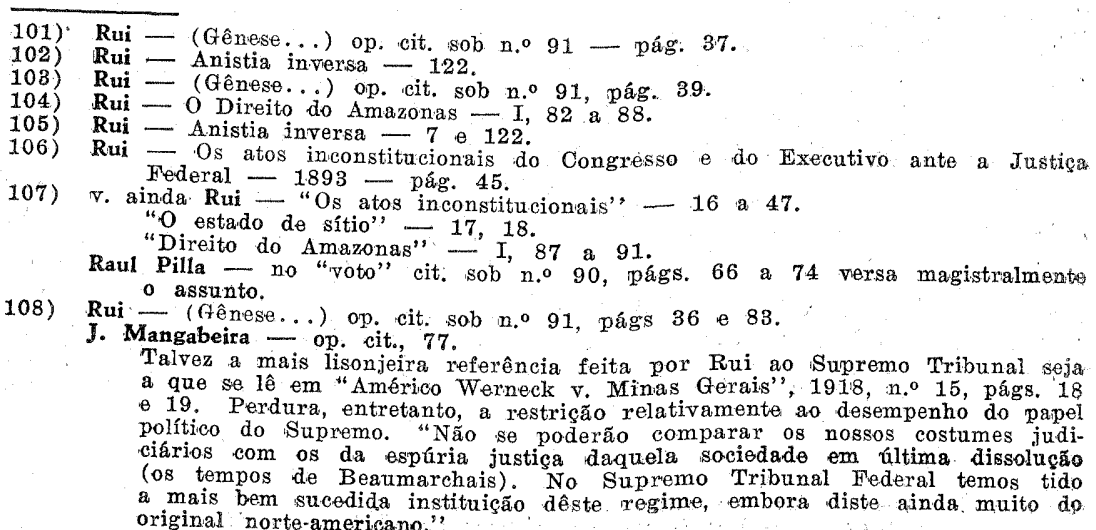
a que se lê em "Américo Werneck v. Minas Gerais", 1918, n.o 15, págs. 1 político do supremo. "Nâo restroderão comparar os nossos costumes pape ciarios com os da espúria justica daquela sociedade em raltima. dissolucão (os tempos de Beaumarchais). No Supremo Tribunal Federal temos tido mais bem sucedida instituiç̃ dêste regime embora diste ainda muito do 


\section{O PRESIDENCIALISMO DA REPÚBLICA E DO 1.: IMPÉRIO}

E após um quarto-de-século de vida republicana, será com o primeiro reinado, antes da evolução parlamentarista, progressiva e pa cientemente procedida ao longo do segundo, que Rui vai comparar a república presidencial. E' ao tempo dos motins e das revoluções, em lugar das moções de desconfiança, que êle remonta para retratar a república à americana.

“...nesta República, depois de 25 anos de existência republicana, retrocedendo todo êsse tempo e aproximando-nos daquele em que o primeiro imperador dispunha das liberdades nacionais...", já tão distinto dos poderes que restavam a Pedro II, pois, "ao govêrno pessoal do imperador, contra o qual tanto nos batemos, sucedeu hoje o govêrno pessoal do presidente da República, requintado num caráter incomparàvelmente mais grave: govêrno pessoal de mandóes, de chefes de partido, govêrno absoluto, sem responsabilidade, arbitrário em tôda a extensão da palavra, negação completa de tôdas as idéias que pregamos, os que nos vimos envolvidos na organização dêsse regime e que trabalhamos com tanta sinceridade para organizá-lo." 109)

Por certo, quando se sacrificara a monarquia e se estabelecera a República, foi "supondo melhorar de instituições, e promover o govêrno da nação pela nação" e nunca para "operar o retrocesso mais violento das conquistas liberais, já consolidadas sob o antigo regime, a um sistema de anarquias e ditaduras, alternativas ou simultâneas, com que contrastam epigramàticamente as formas de uma democracia esfarrapada." 110)

Comparar, por isso, os resultados do presidencialismo com os da monarquia parlamentar que se aprimorava nas regras do govêrno de gabinete, seria "estabelecer um paralelo monstruosamente injusto entre o antigo regime e o atual, sob o aspecto do respeito à lei e à ordem, à liberdade e à honra", como falava ao Senado ao cabo do govêrno Hermes. E nessa mesma filípica prodigiosa em que rivalizam os cimos da eloqüência política com os modelos clássicos da beleza literária Rui cachoa com êste julgamento definitivo:

"Um mês de govêrno Hermes, sobraria, no Império, para fazer cair 50 gabinetes. Os abusos, as preterições de direitos, os excessos do poder, contra os quais, em 1889 , eu assentava baterias no "Diário de Notícias" combatendo o ministério João Alfredo e o ministério Ouro Prêto, dariam que rir hoje aos mais severos catôés republicanos. Se as vibrações que de casos tais extraiu então a imprensa, encheram, abala-

109) Rui 二 "Com." - III - -320 e 312 (Senado, 16-VI-914).

cf. Mirkine - Les Const. des nations americaines - XO ram e levantaram a Nação, é que esta ainda não perdera o seu pudor, e o tinha muito melindrável. Nada honra mais o Império do que essa sensibilidade, notável prova de que êle não nos extingüira o senso moral, não nos obliterara o civismo, não nos aborrecera da honestidade. Eis aí por onde se estabelece a diferença entre os dois regimes."

"Não é com o exemplo de uma ou outra injustiça, uma ou outra fraqueza, uma ou outra pequenez do imperador que se há de caracterizar o reinado e o sistema de govêrno. O Império (e o seu sistema de govêrno) se definia com a sua alta moralidade, a elevação do crédito nacional e os grandes nomes que ilustraram o regime. A República (igualmente com o seu sistema) se debuxa com a extinção dos nomes nacio. nais, com o achatamento geral da inteligência, no govêrno e nos corpos deliberativos, com a ostentação habitual da mudez nos escândalos reinantes, com a consagração da soberania da ignorância, com a solene proclamação do princípio da competência da incapacidade universal nos chefes de Estado, nos ministros, nos partidos, nos árbitros das situaçôes, com a guerra, enfim, à justiça, enxovalhada com o título de ditadura pelos mais servís cortesãos de tôdas as ditaduras do poder das armas e do tesouro." i11)

As novas "formas constitucionais" a que aludira em 99, nas páginas da "Imprensa", haviam frutificado. Falhara em tôda linha a teórica harmonia do regime.

Refletindo essas conclusões, em 916, ao renunciar o lugar na Comissão de Finanças, para a qual fôra eleito, depois de repelir a crise financeira como argumento que dissuadisse "qualquer reforma no mecanismo legal e constitucional de que ela é resultado," discorria assim:

"eu não poderia encontrar em mim a coragem de recomendar à população brasileira, já tão sobrecarregada, a resignação aos novos sacrifícios, cuja necessidade lhe vai ser ditada pelos extremos em que se debate o Tesouro Nacional, sem que, ao mesmo tempo, me fôsse dado anunciar que a política nacional, abraçando a causa das reformas necessárias, das reformas urgentes nas nossas instituições, se desempenhava em estancar aos mananciais das torrentes de abusos, onde incontestàvelmente derivaram as desgraças da atualidade financeira, às quais, enquanto se não atalharem as causas permanentes, nunca se poderão assegurar verdadeiras melhoras."

"Separando-se os dous têrmos, agravando-se a carga tributária, ao mesmo tempo em que se dilatam sine die as reformas políticas, o problema não tem solução que satisfaça ao bom senso e tranqüilize a justa ansiedade popular. Uma nação de quem se reclama contingentes cada vez mais gravosos para a reconstituição das suas finanças não os pode

111) Rui - (Gênese...) op. cit. sob n.०91-82 e 83 
admitir de boa vontade, sem que veja os seus homens públicos deliberados a extirpar do regime do seu Govêrno o cancro da irresponsabilidade, que as arruinou, e contra a qual não há remédios na legalidade estabelecida." 112)

E em 17, reflexionava a um jornalista francês: "discute-se hoje com muito calor, na tribuna e na imprensa, a questão de saber se, no tocante a essas instituiçôes funestas que tornam irresponsáveis os governos, e estabelecem o predomínio da incapacidade, o remédio não seria substituir a república presidencial pela república parlamentar. Quanto a mim, apesar de tudo, hesito ainda. Mas começo a sentir que não haverá talvez nenhum outro meio de chegar, entre nós, a um gom vêrno realmente democrático, fundando a responsabilidade do poder perante o povo, e chamando o mérito e a capacidade à partilha do poder, à gestão das finanças, à administração dos negócios estrangeiros e à elaboração da lei. Não se poderão adiar por muito tempo reformas. tão essenciais sob pena de lançar o país na desordem, e comprometer os interêsses mais caros de seu crédito e da sua existência mesma." 113)

\section{PARLAMENTARISMO E FEDERAÇÃO}

Escorchara-se, evidentemente, do preconceito, que ajudava a divulgar, acêrca das incompatibilidades essenciais entre o parlamentarismo e a federação, ${ }^{114}$ ) pois, havia um ano, orando na Argentina, no salão de "La Prensa", pontificava:

"com a República e a federação, ou havemos de nos salvar, ou de perecer. Podemos, devemos reconstituílas e saneá-las. E $\mathrm{E}$ que com o nosso revisionismo queremos. Os males da federação e os da República são males que se curam, não pela abolição de uma ou de outra, mas pela reorganização de uma e outra. Temos praticado mal essas duas grandes instituições. Mas não melhoraríamos, acabando com elas, senão praticando-as melhor, o que será exeqüivel, se o quisermos."

E após acentuar que a federação entre nós "era fatal" e que uma vez estabelecida tornava-se irrevogável, tal a energia adesiva daquela instituição ao país que a adotasse, asseverava que "sejam quais forem as revisóes, por. que passe o nosso direito constitucional, neste ponto vital não se ousará jamais tocar." 115)

A fórmula salvadora, em 89 , não "estava em práticar sèriamente o govêrno parlamentar e conceder à opinião nacional, inclinada nessa

112) Rui $\quad$ Rui $\begin{gathered}\text { Correspondência } \\ \text { 113) }\end{gathered}$ cit. por Olímpio Ferraz.

113) Rui - cit. por Olimpio Ferraz de Carralho - op. cit., 342 e por Agenor de

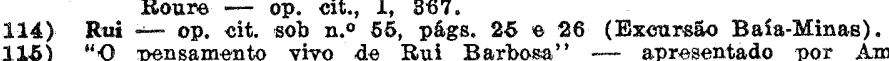

115) "O pensamento vivo de Rui Barbosa" - apresentado por Américo Jacobina direção desde 1831 , a grande descentralização, a saber: a federalização das províncias sob a presidência parlamentar da monarquia?" 116)

Pois com tal bandeira Rui ficou vencido no Congresso Liberal e, fiel a ela, na direção do "Diário de Notícias" e não no ministério Ouro Preto. ${ }^{117}$ )

Foi um preconceito que durou. Mas não valia mais do que aquêle divulgado por Campos Sales, o de ser inerente à monarquia o parlamentarismo, como sòmente ao regime presidencial se ajustar a república.

Os regimes presidencial e parlamentar dizem respeito ao sistema de relações entre os poderes, sendo indiferente às formas de govêrno republicana ou monárquica, e de Estado, unitária ou federal. Nesta há um govêrno central responsável perante a Câmara, e governos estaduais, que respondem perante as respectivas Assembléias. A queda de um náo acarreta a de outros, pois, as esferas de ação e competência são distintas e não se chocam. ${ }^{118}$ )

\section{ÚLTIMA HESITAÇÃO}

A hesitação manifestada ao jornalista francês, porém, tende a desaparecer. Não haveria meio de chegar-se a um "govêrno realmente democrático", senão fundando a responsabilidade do poder perante o povo, tal como sucede no regime parlamentar, "o que quer dizer, onde existe responsabilidade para o govêrno", pois só êle estabelece um equilíbrio entre govêrno, parlamento e povo, através das técnicas da responsabilidade política e da dis̀solução parlamentar.

A hesitação se prolonga até a entrevista que concede ao "Correio do Povo", de Pôrto Alegre. Resumindo o seu sentir, relativamente à reforma constitucional, nos têrmos do programa civilista, no aspecto analisado, e recitando a passagem referente ao "problema ainda não maduro, contra o qual as exigências da ortodoxia republicana são até agora irredutíveis", comenta: "estas palavras, explanando a cláusula nona da enumeração, mantém o regime presidencial, pondo fora de tôdas as minhas cogitaçôes o parlamentarismo como pretensão de atualidade." 119)

Mas se a reforma no sentido da adoção do govêrno de gabinete fu-

116) Rui - Queda do. Império - introd. XXvir.

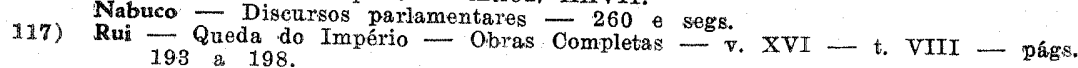
Nabuco - Discursos parlamentares, 372,3 .

Viana F. ${ }^{\circ}$ - op. cit., 187

118) Raul Pille Morais - op cit, 111 .

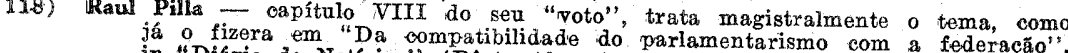

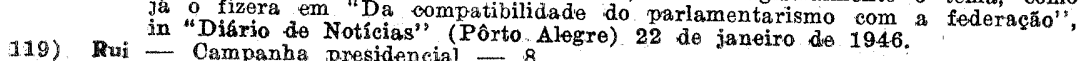


gia de ser pretensão de atualidade, é que já não lhe era contrária a sua posição. E haveria de surgir o momento oportuno para advogá-la, preconizando-a como o único meio de chegar "a um govêrno realmente democrático."

Mas eram falsos os motivos assoalhados pelo oficialismo, especialmente do Rio Grande do Sul, terra onde se "pontificava direito constitucional aos levitas do alcorão", e para onde se dirigia a entrevista. Não era a pureza formal da Constituição de 24 de fevereiro o que se queria conservar, mas a preservação da "mais vil das comborçarias (que) se converte de quatriênio em quatriênio em moral do regime." ${ }^{120}$ ) Em carta a Nilo Peçanha, na época, dissera que "a política brasileira quer a Constituição inalterada para a violar. Nós a queremos reformada, para a conservar." ${ }^{121}$ )

\section{PARLAMENTARISMO, PRETENSÃO DE ATUALIDADE}

Talvez tenha sido a repetição do subterfúgio do situacionismo o que haja transformado em "pretensão de atualidade" a reforma parlamentarista, porque, explicaria Rui, num dos seus últimos escritos:

"essa intransigência em que o nosso mundo político se abrasa pelo sistema presidencial, negando pão e água a qualquer traço de ensaio das formas parlamentares, não se origina, realmente, de nenhum dos motivos assoalhados, não tem nascença em considerações de ordem superior, não vem de que os nossos políticos bebam os ares pela verdadeira prática republicana. Não. Pelo contrário, o de que se anda em cata, é só da irresponsabilidade na política e na administração." 122)

$\mathbf{E}$ é assim que os paralelos entre os dois regimes se sucedem nas conferências eleitorais, logo após proferidas, paralelos sempre concludentes em favor do parlamentarismo.

$\mathrm{Na}$ dirigida às classes conservadoras, confessaria que "o regime constitucional na monarquia, tinha, entre nós, dois largos pulmões, o parlamento e a imprensa, por onde a vida nacional se oxigenava livremente. $O$ nome do senado não desdizia, ali, das tradições da majestade antiga, não repugnava às grandezas consulares da casa de Cícero e Catão. A tribuna legislativa era a gloriosa arena, onde as idéias e as virtudes se batiam pelas aspiraçóes da honra e do civismo."

"Outros tempos desbancaram o ranço dessas futilidades. As belezas do presidencialismo brasileiro escorraçaram dos augustos laboratórios da legislação republicana o talento, a eloqüência e a verdade baixaram, de legislatura em legislatura, naqueles recintos consagrados

120) Rui - Campanha presidencial - 69 :

122) Rui "A imprensa e o dever da verdade" 127 pág. 21. à caricatura da soberania nacional, o nível da capacidade e do decôro, da independência e da respeitabilidade, poluíram a vida parlamentar de chagas inconfessáveis, de segredos tenebrosos, de pústulas vergonhosas e máculas sem nome." 123 )

E na oração que disse em Juiz de Fora, é assim que se refere aos frutos do regime que transformou "o govêrno constitucional em govêrno conventicular": ${ }^{124}$ ) "Quais são os grandes povos, os povos de atividade, os povos em vigor, os povos de soberania? São os povos, a quem Deus deu quem lhes fale. Um povo, que não tem quem lhe fale, perde o hábito de ouvir: com o descostume de ouvir, acaba perdendo o ouvido: e, porque já não ouve, se desaveza de falar, para ao cabo, perder, também, a fala. No fim de contas se reduziu a uma pesada massa incônscia e surdo-muda: porque, à fôrça de não escutar nada, se lhe gastou a oitiva e a linguagem, mergulhando-se-lhe a vida na surdez e na afasia. Ora, trinta anos há que o povo brasileiro se acha condenado a êste regime. Na monarquia havia vozes, a audição popular exercitava-se, e, pela audição, se exercitava a consciência do povo. Por isso, com a monarquia, se fêz o sete de abril, se logrou o vinte e oito de setembro, se conseguiu o treze de maio, se chegou ao quinze de novem. bro. Resgatou-se a nação do colonialismo. Remiu-se da escravidão o trabalho. Emancipou-se da centralização a vida local."

\section{A OPINIÃO JARRETADA}

E' que o regime presidencial, sendo um regime que marca sòmente os anos da opinião pública, por ocasião das eleições, forrando-se após à sua influência, atrofia os partidos e mergulha a opinião popular no "mais muçulmano dos fatalismos"; os governos, congressos e executivos, eleitos por prazo fixo, são inamovíveis e incomovíveis, e a democracia é muda, surda e paralítica. Em uma palavra: uma democracia primária, ancilosada, trôpega.

Eis porque "a nossa revolução estabeleceu o silêncio. A república aferrolhou, trancou e chapeou a porta, por onde entrava, não sei se para que por ela também a não pusessem, algum dia, no ôlho da rua. As formas do novo regime mataram a palavra. Deixaram o mecanismo das instituições legislativas. Mas, acastelando o govêrno em um sistema cabal de irresponsabilidade, emancipando-o totalmente dos freios parlamentares, reduziram a tribuna a um simulacro de locutório, insulado no vazio."

"A nação não ouve o que dali se diz; porque o que dali se diz, não tendo autoridade alguma, nenhum prestígio, nenhum eco, nenhuma

123)
Rui - Campanha presidencial -68. 
repercussão pode ter. Com o govêrno parlamentar as câmaras legislativas constituem uma escola. Com o presidencialismo, uma praça de negócios. O segrêdo, que agora se quer banir da diplomacia, é a essência do govêrno interno sob as nossas instituições."

"Os debates, na representação nacional, não servem para deixar ver a verdade sôbre o govêrno da nação. Para o que servem é para a encobrir. Seu papel dissimulativo os rebaixa. Sua baixeza os entrega à mediocridade. Sua mediocridade os inutiliza. Sua inutilidade os separa do povo, que os aborrece, os evita, os ignora, e se habitua a não os escutar. Destarte, abandonada pelo merecimento, que ali nada tem que fazer, e esquivada pelo povo, que dali nada tem que ouvir, à tribuna parlamentar sobreresta ainda a palavra, que outrora a animava, mas reduzida a um anacronismo." ${ }^{125}$ )

\section{O REGIME E AS CAMPANHAS IDEOLOGICAS}

Durante a mesma campanha, a sua campanha da França, de Napoleão, em 1814, sem o grande exército, com os Maria-luizas, na comparação sugestiva de seu grande discípulo, o abolicionista, o pregador, o justiceiro apóstolo, dirigindo-se aos operários, na conferência que dedicou ao exame da questão social, salientando o hiato verificado após a República presidencialista, no plano das conquistas sociais, abraçava, por fim, a conclusão:

“... a República, reacionária desde o seu comêço, e desde o seu comêco imersa no egoísmo da política do poder pelo poder, traidora desde o seu comêco aos seus compromissos, tinha muito em que ocupar a sua gente, para ir esperdiçar o tempo com assuntos sociais."

"Nem mesmo quando algum dos lidadores da campanha recémterminada (abolicionista) se animasse a encetar a segunda, haveria onde a lograsse abrir com vantagem: porque só no govêrno parlamentar existe o terreno capaz de dar teatro a essas cruzadas morais, a essas lutas pelas idéias nas regiões mais altas da palavra, onde elas se fecundam. No presidencialismo não há senão um poder verdadeiro: o do chefe da nação, exclusivo depositário da autoridade para o bem e para o mal." ${ }^{126}$ )

Porque "hoje, poder e povo, maioria e minoria, oposição e govêrno tudo são nomes. Só uma coisa existe: o chefe do poder executivo. Não sòmente o chefe do poder executivo na União. Basta ser o chefe do poder executivo num Estado. Mais ou menos graúdo, mais ou menos grado, nada importa a grandeza. Estado, estadinho, ou estadão, todo Estado é Estado, e em cada Estado, o chefe do poder executivo,

125).
Rui
Rui atualmente, mete nos seus chinelos os ministros do imperador e a própria majestade imperial." ${ }^{127}$ )

\section{ATUALIDADE DA REFORMA}

Não havia dúvida que, como previra nos idos de 1893, eclipsada a responsabilidade, "todos os poderes do Estado vão sucessivamente desaparecendo no executivo, como nas espirais revoluteantes de um sorvedouro."

Por isso dizia Rui, - tão absorvido no exame das soluções do problema social, - numa carta a Maurício de Lacerda, em 1921, que "não é a questão social que enche ainda o cenário da política brasileira. $O$ que tudo domina é o problema político-administrativo." "128)

Até quando seria o Brasil dominado por um "Govêrno ultra-pessoal, debaixo dos sórdidos e esfarrapados trapos republicanos"? ${ }^{129}$ )

Porque, em última análise, "nas repúblicas de molde presidencial, em que aqui se levava a mira, os reis temporários e corrilheiros, designados a capricho das camarilhas oligárquicas e máquinas eleitorais, escondendo mal escondida a sua onipotência real no eufemismo convencional de presidência, obram sem corretivo, com um poder irresponsável e, por conseqüência, ilimitado, imoral, absoluto," dizia o mestre, em 921, na introdução à "Queda do Império". E logo ao seu início conjeturava: "os cegos do novo regime entrarão numa cura de humildade, reconhecendo que o outro caiu por um milésimo dos vícios e males, a que êste se entrega, descuidada e irresponsàvelmente, de corpo e alma." 130 )

Em tal regime, "a tribuna parlamentar é uma cratera extinta, e as câmaras legislativas mera sombra da representação nacional." 131)

Num regime que "em vez de ser governado por uma Comissão do Parlamento, é regido pela discrição de um homem" e sôbre o qual "nenhuma ação têm os ministros e o Congresso", o destino das figuras independentes, ainda que ilustres e capacíssimas, será esperar pela justiça dos pósteros, pois a sua condição haverá de ser "ociosa e triste de vox clamantis in deserto", "corpo estranho, hóspede impertinente" 13") ou então lutar, mais ou menos estèrilmente, até ser dominado por aquela convicção amarga que Rui traduziu nestas palavras:

"Busquei servir ao meu país e ao meu Estado natal, enquanto estive no êrro de supor que lhes podia ser útil. Mas, acabando, por fim, de ver que não tenho meio de conseguir nada a bem dos princípios, a

127) Rui - Uma campanha política - (1919) - ed. Homero Pires, 1932, pág. 192

127) Rui - Uma campanha política

129) Rui - Correspondência - 420.

130) Rui 二 Queda do Império - introd. XXI. 
que consagrei mirha vida, e que a lealdade a essas convicções me tornou corpo estranho na política brasileira, renuncio ao lugar, que, em quase contínua luta, ocupo, neste regime, desde o seu comêço, deixando a vida política, para me votar a outros deveres. Não era nova, em mim, essa triste e dolorosa impressão. Longos e longos anos havia que ela me vinha crescendo no ânimo, com o malôgro de todos os meios envidados, para ter mão na República em sua vertiginosa queda moral e constitucional." 133)

Nas páginas de "A imprensa e o dever da verdade", conferência que escreveu e, colhido pela morte, não chegou a proferir, pregaria ainda:

"Só onde os povos se costumaram a tomar contas aos seus administradores, e êstes a dar-lhes, é que os homens públicos apreciam as vantagens dos regimes de responsabilidade."

"Nestes aleijôes constitucionais da América latina, como o Brasil, nestes míseros tolhiços de repúblicas, que, tais qual o pau torto de nascença, tarde, mal ou nunca se endireitam, o ideal dos governos está na irresponsabilidade."

"Essa intransigência em que o nosso mundo político se abrasa pelo sistema presidencial, negando pão e água a qualquer traço de ensaio das formas parlamentares, não se origina, realmente, de nenhum dos motivos assoalhados, não tem nascença em considerações de ordem su perior, não vem de que os nossos políticos bebam os ares pela verdadeira prática republicana. Não. Pelo contrário, o de que se anda em cata, é só da irresponsabilidade na política e na administração."

" $\mathrm{Na}$ irresponsabilidade vai dar, naturalmente, o presidencialismo, 0 presidencialismo, se não em teoria, com certeza pràticamente, vem a ser, de ordinário, um sistema de govêrno irresponsável." 134)

\section{VOX CLAMANTIS IN DESERTO}

A evolução se completara. Estava amaldiçoado o mecanismo em que, insensível à opinião, o exercício do poder é o único instrumento eficaz para o bem, e que, por isso, reduzia um homem daquele merecimento extraordinário a um "corpo estranho na política brasileira", a um hóspede impertinente dela, que o condenara enfim à "maldição de um ingrato duelo com o irrealizável," 135) quando já no parlamento imperial, moço ainda, se saíra em obras memoráveis e benfazejas.

No republicano, onde "não há senão um poder verdadeiro: o do chefe da nação, exclusivo depositário para o bem e para o mal," "sem

133) Rui - Correspondência - 420.

134) Rui Ditadura e Repáblica-245. (Senado-30-VII-921).

$\begin{array}{ll}\text { 134) } & \text { Rui } \\ \text { 135) A Imprensa e o } & \text { Rui }- \text { Oswaldo Oruz, } \\ & \text {. }\end{array}$ autoridade para qualquer iniciativa suscetível de resultado, a (minha) sua tarefa, no meio das batalhas pessoais em que se debate a impotência do parlamento, se viu reduzida a bradar pelas leis que se imolam, e contra os abusos que se consumam." ${ }^{136}$ )

\section{DO BEM PARA O MELHOR}

Libertara-se cabalmente da cruz de que fôra martir, através da sua pregação de mestre-escola do regime. Nem se conceberia um espírito democrático e liberal sufragando um sistema de govêrno contemporâneo do vigente ao tempo de Jorge III. Porque, històricamente, o govêrno de gabinete é uma superação democrática da simples monarquia constitucional e o presidencialismo, um seu eqüivalente sob a forma republicana.

Ao Senado uma vez dissera Rui: "nunca me presumi de infalível; não me presumo senão da vontade de acertar e me emendar nos meus erros." 137)

Tão evidente era a reforma, profunda e fundamental, processada na ideologia de Rui, que não passou despercebida aos seus adversários. Um dêles, depois de repetir trechos da conferência de 92, na Baía, na qual o ex-ministro do govêrno provisório mencionava como capitais inimigos da ordem republicana: "o militarismo e o parlamentarismo", pas. sou a citar discursos recentes, da campanha eleitoral de 19, para concluir sob o título irônico "Parlamentarismo... salvação da Repú. blica": "atualmente já muito outra é a sua opinião. O parlamentarismo, êsse grande inimigo da República, passou a ser a sua única salva. cão. Já não existem essas incompatibilidades com o regime federativo. Ao contrário." E depois: "Atendestes? E' o sr. Rui Barbosa combatendo o sr. Rui Barbosa." 138)

Mas a réplica já existia. Num trabalho jurídico magistral, como tudo que lhe brotou da pena, advertira um dia: "só a ignorância ou a imbecilidade se não contradizem; porque não são capazes de pensar. Só a vulgaridade e a esterilidade não variam; porque são a eterna repetição de si mesmas. Só os sábios baratos e os néscios caros podem ter o curso das suas idéias igual e uniforme como ós livros de uma casa de comércio; porque nunca escreveram nada seu, nem conceberam nada novo."

E mais adiante: "debaixo do céu, tudo obedece a essa eterna leì da transmudação incessante das coisas. Se nihil sub sole novum, também poderíamos dizer que nihil sub sole constans. Se todo o mundo se compõe de contradições, dessas contradições é que resulta a harmo.

136) Rui - Campanha presidencial - 119.

138) Ru Com." - TV 239 . (Senado - 22-1-915). 
nia do mundo. Se das variações pode emanar o êrro, sem as varia. ções o êrro não se corrige. A boa filosofia é a de Joubert, quando nos aconselha que, se por amor da verdade, houvermos de cair em contradições, não vacilemos de nos expor a elas de corpo e alma. Se "a razão nunca está em contradição consigo mesma, quando segue as suas leis", como dizia o honesto Júlio Simon, a única espécie de contradição, de que o espírito se há de arrecear, é a de se empedernir no êrro, quando enxerga a verdade. O homem não está em contradição consigo mesmo, senão quando o está com a sua natureza moral, que o ensina a considerar-se desonrado, quando atina com a verdade, e se obceca no êrro. $\mathbb{E}^{9}$ assim que o nosso próprio organismo vive, mudando tôda hora, sem mudar nunca; porque da sua identidade realmente não muda, senão quando, quebradas as suas leis orgânicas pela doença ou pela morte, deixa de eliminar o que deve eliminar, e absorver o que lhe convém absorver." ${ }^{139}$ )

E na introdução à "Queda do Império" voltaria ao tema: "pelo que toca ao variar das opiniões, deixem-me ter, mais uma vez, o consôlo de trazer à praça como coisa de que me prezo, e não me pesa, a culpa dos homens de consciência, a única em que hei de morrer impenitente." E em seqüência: "é sempre do menos para o mais, suponho eu, do mal para o bem, ou do bem para o melhor que tenho mudado, ou feito por mudar, com especialidade nos trinta e três anos que vêm da agonia do outro regime a isto, que não sei como se chame, do atual." ${ }^{140}$ )

\section{EVOLUÇÃO DAS INSTITUIÇõES}

A evolução operada no pensamento de Rui repetia a da história constitucional do império.

O regime presidencial, contrabandeado à sombra da República e da Federação, foi uma secção, um corte na linha evolutiva das instituições democráticas em nosso país. ${ }^{141}$ )

Aliás, o projeto de emenda constitucional parlamentarista que tramita no Congresso "visa justamente reatar a interrompida tradição democrática do Brasil, instituindo, com a Federação e a República, o sistema parlamentar." 142)

139) Rui - Questão Minas Werneck - Competência do Supremo Tribunal Federal 140) nas a pelaçóes de sentenças arbitrais 104 e 106

140) Rui - Queda do Império - int. od. LXXXVI. "Át em sua essência tôda as história Maria dos Santos - op. cit., 219. Aí está em sua essência tôda a historia nossa evolução política, romperam-se na nossa vida pública tôdas as relaçōes de sequiência e continuidade, e, tudo quanto até entấo possúramos como ins trumentos legais da libe:dade, eomo p áticas e costumes penosamente apu-
rados e afinal estabelecidos, tudo foi radical e simplesmente identificado como sendo a próp:ia monarquia, e confundido com o trono para ruir e desapaRaul Pilla - "voto" citado sob n.o 90 - cap. IV - item "d".

142) Raul Pilla - "voto" citado sob n.o 90 - cap. ${ }^{\text {Ralla }}$ - "voto" cit. sob n.o 90 , pág. 27.
Com efeito, o surto constitucionalista nas monarquias foi a primeira limitação ao absolutismo dos reis, "a lei animada sôbre a terra", na linguagem das velhas Ordenações. ${ }^{143}$ )

Só posteriormente se distinguirá no poder executivo uma parte estável e outra móvel, complementando a divisão do poder em três ramos distintos. Será quando o executivo se dicotomizar em duas entidades, a que representa o Estado em sua soberania, a nação na superior unidade de seus interêsses, e a que, exercitando o govêrno, velará pela política, com apoio na maioria; e correlata e simultâneamente, acrescendo à sua primitiva e restrita competência orçamentária, a de conceder ou negar apoio ao gabinete, parte móvel do executivo, a Câmara tornar-se-á tão responsável perante o povo, quanto o ministério perante ela." 144)

Despersonaliza-se o poder. Êle se institucionaliza. Surge o govêr. no parlamentar. ${ }^{145}$ )

No presidencialismo, onde o govêrno é pessoalmente conduzido pelo chefe do Estado e, em tôrno do qual, como meros auxiliares, se homogenizam os ministros, como o presidente, ininfluenciáveis pelas Câmaras, há uma eqüivalência à fase da monarquia meramente constitucional, ${ }^{146}$ ) antes de evoluir em parlamentar, momento em que, permanecendo irresponsável o soberano que não mais governa, é estabele cida a efetiva responsabilidade, coletiva e solidária, para o "govêrno em função." 147)

Não excecionou o Brasil à regra presidente da evolução institucional dos povos. Existiu entre nós, de fato e de direito, o govêrno pessoal do soberano. Cabia-lhe o poder de livremente nomear e demitir os ministros, cuja permanência no govêrno se prendia à sua vontade e não à confiança da maioria. Inexistia a responsabilidade política, individual ou coletiva, a figura do presidente do Conselho era inexistente, o ministério, como entidade autônoma, também o era. Nada obrigava o imperador a escolher os ministros dentre os parlamentares e a dissolução da Câmara só era cabível em caso de salvação pública. ${ }^{148}$ )

Os poderes que, pela Carta de 25 de março de 1824, desfrutava o

143) Ord. Fil. L. III, tít. 60, parágrafo 1.0.

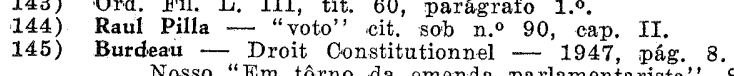

146) Kelsen - "Em tôrno da emenda parlamentarista"," Separata da "Justiça", 1949.

grafo $37 \mathrm{D}$, pág. 338 . 1923 , pág. 44.

147) Nosso "Em tôrno ao Brasil, v. Raul Pilla - "voto" cit., pág. 12

148) Olimpio Ferraz de Carvalho - par, cit., 319 e se

Afonso Celso - Oito anos de parlamento - 289 e segs.
Raul Pilla - voto" cit. sob n.o 90, cap. IV. 
imperante semelhavam aos que teria o presidente da República de 91. ${ }^{149}$ )

Aliás, a própria Inglaterra não atingira a fase áurea daquele "gow vêrno responsável", que é a sua contribuição peculiar à ciência políw. tica, no conceito de Jennings. ${ }^{150}$ )

Entre nós, foi a despeito da lei constitucional e contra ela que o. govêrno de gabinete se entreteceu. "O parlamentarismo foi no Brasil uma lenta conquista do espírito público, jamais consagrada em lei. Es. tribava-se no direito costumeiro, não no direito escrito." E como Afonso Celso, Joaquim Nabuco registra o mesmo fenômeno. "O regime parlamentar foi-se constituindo lentamente entre nós. A compreensão da. Constituição variou fundamentalmente de geração em geração."

Por isso Oliveira Lima historiou que "a idade d'ouro do regime parlamentar brasileiro não data, como sucede com o geral das lendas. da civilização humana, do comêço da sua evolução, e sim do meado da. sua duração." 151

\section{A SURPRESSA PRESIDENCIALISTA}

E' de notar-se, outrossim, que a propaganda anti-monárquica não. se orientou contra o sistema, mas contra as suas imperfeições e, é claro, contra as formas de govêrno monárquico e de Estado unitário. ${ }^{152}$ )

Rui, o liberal independente do último ano do império, declarando. que "as monarquias republicanizam-se mediante as instituições parlamentares, assim como as repúblicas se cesarizam pela ditadura", não. passou de um "tenaz adversário da polítiça pessoal", indicando com eloqüência residir a fórmula salvadora da coroa "em praticar sèria" mente o govêrno parlamentar e conceder à opinião nacional, inclinada nessa direção desde 1831, a grande descentralização, a saber: federali.zação das províncias, sob a presidência parlamentar da monarquia."

Porque a sua consciência de "monarquista parlamentar", como sẹ retratava em 21 , lhe indicava que "a democracia moderna fêz das monarquias parlamentares verdadeiras repúblicas coroadas." 153)

E nas invectivas do Manifesto Republicano de 70, os históricos. não colimavam o regime americano de govêrno, senão o contrário.

"A soberania nacional, rezava êle, só pode existir, só pode ser reconhecida e praticada em uma nação cujo parlamento, eleito pela partí

149) Otávio Tarquínio de Souza - Diogo Antônio Feijó - 222

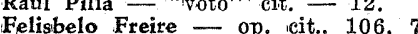

150) W. Ivor Jennings - op. cit. sob n.o $85-167$.

151) Afonso Celso - Oito anos... 289.

152) Oliveira Lima -0

Américo Brasiliense - op: cit., 85

153) Rui - Queda do Império - introd. XxIX cipação de todos os cidadãos, tenha a suprema direcão e pronuncie a última palavra nos públicos negócios."

Tal assertiva se deduzia da premissa segundo a qual "neste país, que se presume constitucional, e onde só deviam ter ação poderes delegados, responsáveis, acontece, por defeito do sistema, que só há um poder ativo, onímodo, onipotente, perpétuo, superior à lei e à opinião, e êsse é justamente o poder sagrado, inviolável e irresponsável." ${ }^{154}$ )

Tudo isso porque "o imperador reina, governa e administra", tese ainda sustentada pelos conservadores - e que posteriormente seria abandonada pelo próprio partido de Itaboraí, através do primeiro Rio Branco ${ }^{155}$ ) - contra a apostolada pelos liberais, à semelhança do whigs ao tempo dos Jorges, segundo a qual o rei reina e não governa.

O manifesto de 70 ainda é um reflexo do generalizado protesto contra a interferência do poder pessoal, pelo menos aparente, refletindo, aliás, outra ordem de interêsses, ao despejar o gabinete Zacarias, em 68, sem uma causa parlamentar que o justificasse, em contrariedade à observância das praxes que se vinham firmando. ${ }^{1.56}$ )

Assim, as "Bases para a Constituição do Estado de São Paulo", formuladas pela comissão permanente do Congresso republicano êste apresentado, em 1873, dispunha que o chefe do executivo seria "de Jivre nomeação e demissão da Assembléia Geral." 157)

Medeiros e Albuquerque esclarece, aliás, que "a propaganda republicana se fêz sem que a maioria pensasse no regime presidencial; não se sabia o que era, não se falava nêle." 158 )

Seria mesmo paradoxal que tanto se combatesse o declinante poder pessoal do imperador, para estabelecer outro, tão efetivo quão incon. trastável, ou mais corretamente, restabelecer aquêle que brandira das

54) Manifesto - in Américo Brasiliense - op. cit., 82, 83, 62.

Oliveite Liantense - op. cit., 13 e 69 .

talmente a máxima dministra, para ir endossando aos poucos o nuovo programa liberal... de 1866 " "voto", cit pán 11

iSôbre as dissoluçōes da dâamara,

. Olimpio F, de Carvalho, op, eit., $270 \ldots$

-Discurso de 13-VIII-1868 - Novos disc. e conf., 5,6

$5,6$.

osé Maria dos Santos - op. cit., cap. VI e VII.

Nota crítica do mesmo autor oferecida ao sr. Raul Pilla, v. "voto" eit. sob Oliveira Lima - op. cit., 84,85 .

Tobias Monteiro - Pesquisas e depoimentos - 15, 16

O. Ferraz de Carvalho op. cit., 264 a 269.

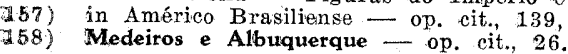


mãos do primeiro imperador, singularizara a regência e lentamente escapara das mãos do segundo. ${ }^{159}$ )

\section{RUPTURA DA TRADIÇÃO}

Foi, destarte, uma surprêsa funesta, além de uma irregularidade histórica, a adoção do presidencialismo, fato só explicável pelas condições da eclosão da República e suas necessárias decorrências, pois " "o velho regime deixara (deixou, diz Campos Sales, nas suas Cartas de Europa) deixara tão fundas raízes, que muitos republicanos históricos pronunciam-se francamente pelo parlamentarismo, e outros há que ainda vacilam perplexos na escolha entre um e outro sistema." ${ }^{160}$ )

A respeito da precipitação da República, prefaciando um livro sôbre o abolicionismo, em 918, depunha Rui que "a república originouse de um acidente gerado pelas desordens de um organismo predisposto pelas suas condições de irresistência e inércia a não lhe resistir. Certas reformas, necessárias, urgentes, improrrogáveis, te-la-iam prevenido e evitado. A nação aceitou-o (o movimento). Mas não era seu. Não havia sido elaborado por ela mesma. Não lhe derivara das entranhas, como o abolicionismo..." 161 )

É, destarte, exata a conclusão. de Agamenon de Magalhães:

"no Brasil o regime presidencial nasceu da influência norte-americana e não sob a pressão de fatos políticos ou de condições existentes. Já a nossa unidade tinha sido realizada pelo Império e as instituiçóes parlamentares estavam em prática, operando a evolução política brasileira para a democracia. A república, portanto, não devia ter interrompido a tradição parlamentar. A federação, sim, era fenômeno geográfico e histórico, trabalhado pelas fôrças descentralizadoras, atuantes

159) Campos Sales - Da propaganda à presidência - 215 - "Os que não puderam ainda compreender bem a essência do regime, tal como o concebeu o nosso fluência exercida legitimamente pela autoridade presidencial, supondo esta na presenea dêsse fantasma do poder pessoal, que outrora atribuíamos, nós. os republicanos principalmente, ao
sidio para os ataques à monarquia.

Existe, é eerto, no regime presidencial, um poder pessoal; mas - $\theta$ nisso que se diferencia do poder pessoal dos soberanos - um poder constitucionalente organizado, com o contrapêso dos outros poderes e, sobretudo, tambén
and Tal a ingênua distinģ̃ôo que se viu forgado a estabelecer, diante do fatos, um propagandista da República e depois seu President

Oliveira Lima - op. cit., 90 - " 0 parlamentarismo foi contudo geralmente praticado no Império com honestidade e brilho suficiente para deixar saudades do pas sado nos espíritos capazes de as alimentar e até para com elas abastecer uma do poder- moderador, restaurando-lhe as prerrogativas pela consagracão da influência do executivo central sôbre os organismos estaduais, dos quais os 160). Campos Sales - Cartas da Europa - in "Estudos de Dir. Const.", de Boutmy

161) Rui - pref. de Lácicio de Mendonga, XXVI. durante o Império. Mas o presidencialismo foi imitação das instituiçóes norte-americanas, criaçấo puramente doutrinária. A nossa educação democrática e as nossas tradiçôes liberais não o impunham." 1.62)

Aliás, é interessante observar que a propaganda se avolumou quando certos argumentos de ordem pessoal, relativos às qualidades e aptidóes da herdeira presuntiva da coroa e seu consorte, se faziam mais convincentes do que a minuciosa organização republicana do futuro ${ }^{163}$ )

Não resta dúvida que os transplantadores do presidencialismo se sentiram tocados "pela sugestão hipnótica da constituição teórica ian que." ${ }^{164}$ )

\section{O AMBIENTE DA EPOCA}

Ter-lhes-á, além disso, parecido necessário, ou prudente, subtrair à influência da Câmara a composição do govêrno, havendo, via, a possibilidade, depois afastada mediante o tristemente célebre regulamento Alvim, dos monarquistas, intelectual, social e numèricamente superiores aos republicanos, preponderarem entre os representantes populares. ${ }^{165}$ )

Sinal dêsse estado dalmá foi a proposta sustentada perante o govêrno provisório, por um de seus membros mais influentes. Cumpria impor a nova Carta, mediante decreto, sem anuência sequer de uma assembléia pré-fabricada através do "mais engenhoso aparelho de fraude eleitoral que se conheceu no Brasil." 166)

"À ditadura compete pôr têrmo à ditadura, argumentava o minis" tro da Justiça Campos Sales. Um govêrno que originou-se da fôrça pode e deve apoiar-se na fôrça para apressar o advento da legalidade." E em seqüência: "A República quer e prometeu fazer a república: isto é, dar ao país uma constituição republicana. Eis o seu compromisso. A escolha do processo pertence aos homens que a dirigem. Estamos, portanto, em um período revolucionário, em que os métodos mais rigorosamente subordinados à doutrina deixam o lugar aos processos mais seguramente eficazes." 167)

E tão bem cumpriria sua missão a nova lei eleitoral, revogadora. da lei Saraiva, que mui pouco lisonjeiro era o conceito popular a res. peito da Constituinte. $\mathrm{O}$ seu presidente, Prudente de Moraes, após pro-

162) Agamenon de Magalhães - $O$ Estado e a realidade contemparânea - 1983,

163) Medeiros e Albuturat

Pinto Ferreira - Principios gerais de Dir. Const. Moderno - 1948, 272 -

165) Afonso Celso - A Década Republicana - II - 224

Antônio Joaquim Ribas \& Perfil biográfico do Dr. M. M. Te dampos Sales, Río,

166) Maximiliano- - pags. 187, 8 .

Raul Pilla - " voto", eit. 24 e 25.
167) Antônio Joaquim Ribas - op. cit., 182,187 
mulgar a Constituição, reconhecia que o Congresso fôra "recebido com desfavor e prevenção pela opinião." 168)

Já em relação à época e ao ambiente da assembléia, Assis Brasil deixou êste retrato: "nenhum pacto fundamental; destinado a longa permanência, foi discutido e fabricado em circunstâncias menos propícias do que o nosso." "Preparada pela fôrça das coisas, desde muito, no mais íntimo da nação brasileira, a mudança radical que começou a 15 de novembro de 1889, não estava, entretanto, igualmente evidenciada nas inteligências. Era maior o trabalho latente de espontânea decomposição da monarquia centralizada, que a formação precisa da consciência cívica no sentido da república federativa. A substituição foi uma surprêsa, senão para todos, para o grande número. Poucos brasileiros estavam conscientemente apercebidos para precisarem a nova fórmula que os fato exigiam no lugar da que se subvertia, por um movimento que, sem ter a essência, teve tôdas as aparências das mutações de teatro. Ainda mes mo quanto aos que fizeram excecão à regra, é fácil de compreender quão pouco eficaz deve ter sido a ação dêles, operando no tumulto dos desorientados, que eram quase a unanimidade." "Havia uma espécie de pêso material, que esmagava os homens de independência moral e intelectual. Não é para maravilhar que algum venha sòmente hoje dizer ao país o que não pôde então explicar." E acrescenta: "Ninguém pareceu ter levado para a Conștituinte idéias orgânicas sistematizadas..." e "a Constituição da República foi discutida e votada na época menos propícia à serenidade e integridade dos espíritos." 169)

Nem de outro modo se explicaria, aliás, a sensível influência exercida pelo grupo positivista, corrente sem raízes nacionais e de escassa expressão numérica no seio do Congresso.

\section{DESVARIOS REFORMISTAS}

Para se apurar como distavam da máxima política formulada por Nabuco, os governantes e legisladores de então, e segundo a qual as reformas devem conservar do existente tudo o que não seja obstáculo ao melhoramento, para se medir o lirismo político dos reformadores e o traumatismo sofrido pela nação, cujas reações mais elementares eram tomadas como suspeitas à República, bastaria lembrar, de uns, o desvario ulțra-federalista, ${ }^{170}$ ) de outros, a ordenança que dispunha: "os estatutos dos povos cultos, especialmente os que regem as relações jurídicas na República dos Estados-Unidos da América do Norte, os casos

168) Anais do Congresso Constituinte. III, 911, 922.
169) Assis Brasil - Do govêrno presidencial -25 ,

169) Assis Brasil - Do govêrno presidencial - 25, 26, 28, 30.

denado a doentio de foderalismo cujo expeñsa por á um apetite desor versão e a rúna da reforma federal". da common law e equity serão subsidiários da jurisprudência e processo federal." "171)

Vê-se, assim, como é exata a aparentemente superficial assertiva de Medeiros e Albuquerque: "Depois, para muita gente, havia em fa vor dêle uma razão verbal, que pode parecer ridícula e fútil, uma razẫo desarrazoada, se assim pode dizer-se. Era uma simples analogia verbal. Nós tínhamos passado a ser os Estados Unidos do Brasil. Logo, de víamos ter as instituições dos Estados Unidos. Todos os que estudam a psicologia das multidóes sabem como as analogias verbais são poderopsicologia das multidõ
sas e influentes." 172 )

A resposta mais eloqüente ao dispositivo citado parece ter sido dada por um dos ilustres ministros do Supremo Tribunal, Barradas, quando interrogava Rui "se era exato que pretendia cassar os atos do Executivo, recorrendo ao Judiciário. Não conhecia ação adequada, nem fundamento jurídico para o caso." 173)

Tamanha era a surprêsa, a novidade, a ignorância das novas instituiçóes, o artificialismo delas, desconhecidas até por quem lhes devia interpretar sem apelação e fixar-lhes, sem recurso, a inteligência.

Homero Pires, ruísta e professor de Direito, elucida que "em 1889 nẫo seriam muitos os brasileiros que conhecessem o direito público norte-americano. Ainda depois, em pleno regime presidencial, the eram atribuídas as maiores heresias, - num meio como o nosso, sobretudo o político, pouco afeito a estudos sérios, mais inclinado a im. provisaçôes fáceis. $O$ conhecimento exato do direito americano sempre ficou limitado a uma elite." 174 )

Evidentemente a escolha fôra infeliz. Arrostava a tradição jurídico-política brasileira e lhe violava as regras de transmissão e evolução das instituições. Foi mister que Rui fôsse "o intérprete das instituiçôes movas e quase desconhecidas." 175)

Um contemporâneo, jurisconsulto de quilate, Clóvis Bevilaqua, não se pejou em confessar que "Rui Barbosa desvendou, aos olhos brasileiros, a ciência do direito público que a América do Norte criara e nós quase ignorávamos que existisse, antes que a víssemos trasladada, em correta e lucilante frase portuguêsa pelo escritor baiano." 176)

Aliás, o próprio Rui ao Senado dizia, em 1915: "quando adotamos dos Estados Unidos esta forma de govêrno, e procuramos adotar o seu delicado e complexo mecanismo aos nossos hábitos políticos, evidentemente a nossa cultura, sobretudo entre as geraçóes que vinham formar

171) Dec. 848 - 11-X-890 - art. 387.

173) Madeiros e Albuquerque - op. cit., 24.

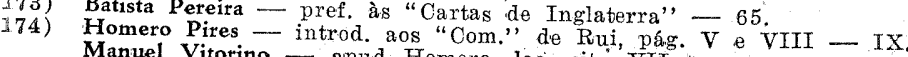

175) Homero Pires - apud Homero, loc. cit., VII.

Clóvis - Juristas Filósofos - $1897-\mathrm{XXXXIII}$ 
a República, era ainda imperfeita no conhecimento da organização da política e da jurisprudência americana. Vinhamos nós da França, da escola francesa, das tradições da grande revolução..." "... essas instituiçôes nos encontraram despreparados para as receber, para as assimilar e para as praticar com aquêle senso do seu espírito, da sua verdade e da sua inteireza, necessário ao desenvolvimento salutar, ao crescimento contínuo, à realidade completa dos ideais que elas vinham introduzir no Brasil." E adiante prossegue: "passamos de um govêrno parlamentar ao govêrno presidencial; passamos do govêrno da tribuna ao govêrno das comissóes parlamentares; passamos de um govêrno de responsabilidade, de um govêrno de merecimento, de um govêrno de conquista das posições pela palavra, a um govêrno de irresponsabilidade parlamentar, a um govêrno dotado, no seu chefe, de prorrogativas quase ditatoriais, a um govêrno que, para ser atualmente praticado, requereria a presença de lições que servissem de corretivo, de freio e de dique eficaz... Nós passávamos repentinamente de um terreno, onde tôdas essas garantias estariam consolidadas no mecanismo, na forma parlamentar, com a presença dos Ministros no seio das Câmaras, com a elegibilidade dos Ministros, com os votos de confiança, com as dissoluções das Câmaras; passávamos de um regime onde tôdas essas garantias se achavam con solidadas dêsse modo, para um regime onde nos encontramos destituídos inteiramente dessas garantias... Nessa transição, os homens que não tinham consigo senão o hábito do fraseado republicano, a fascina. ção das idéias de 89, a educação dos hábitos da escola francesa, êsses homens se achavam baldos completamente daquilo que lhes era mais essencial para empreender a realização exata da forma de govêrno que acabávamos de adotar." ${ }^{177}$ )

Parece assim não assistir razão a Luiz Delgado, tão inteligente, arguto e correto no precioso ensaio que dedicou à interpretação de Rui, ao dizer que "nem foi também por um capricho erudito ou uma aventurosa imitação, que a lei constitucional de 1891 fundou entre nós o presidencialismo." ${ }^{178}$ )

\section{CONCLUSÕES}

A adoção do presidencialismo constituiu uma ruptura ostensiva com as instituições nacionais, e com as regras de transmissão e evolução delas, com aquela Constituição, de que fala Nabuco, antecipando-se à melhor pesquisa sociológica, que "terá sempre que ser o modus-vivendi que os poderes assentarem entre si e que o país tiver sancionado." ${ }^{179}$ )

177) Rui - "Com." I - V a VII (Senado - fer. de 1915)

179) Luiz Delgado - op. cit., 159 .

Mas chega de "evidências, para estabelecer esta evidência evidentíssima." 180)

Embora seja discutivel tenha sido Rui "o transplantador do pre sidencialismo para o Brasil", na frase do autorizado Homero Pires, ainda que "só um homem nesse momento fôsse (era) conhecedor profundo do regime americano", como, em sintonia com Homero, afirma Américo Jacobina Lacombe, assertivas que se afinam ao depoímento de Rodrigo Otávio, quando escreveu que no govêrno "não havia senão êle para apresentar e defender os princípios do regime americano", certo é que Rui, completando o trabalho da comissão de juristas, à luz da experiência centenária do processo constitucional americano, aceitou e defendeu o sistema presidencial de govêrno, e o fêz pelo menos, por exclusão. ${ }^{181}$ )

Mas não menos certo foi o seu repúdio posterior ao presidencialismo, que evitava "o rigor da teoria democrática" ${ }^{182}$ ), e a fixação das suas preferências no "regime parlamentar, o que quer dizer, onde existe responsabilidade para o govêrno."

Esta é a "certeza certa e a verdade verdadeira, evidenciadá e autêntica." 183)

\section{LEGADO AOS DISCIPULOS}

Em mais de uma cláusula, a Constituição de 18 de setembro, como já o fizera a de 1934, assimilou aos seus textos a experiência ideológica de Rui. Constitui mesmo um dos temas do Congresso de Direito Constitucional que em sua homenagem se reúne na Baía, a apuração dessa influência.

A adoção do govêrno de gabinete no Brasil significará assim uma vitória do espírito de Rui, imortalizado em sua obra e seus exemplos.

O velho cruzado terá cumprido mais um pedaço do seu ideal, dos seus ideais grandes e belos em contraste com os frutos de sua vida escassos e tristes. ${ }^{184}$ )

Prossegue o apóstolo inculcando "ao povo os hábitos da liberdade e à República as leis do bom govêrno, que prosperam os Estados, moralizam as sociedadès e honram as nações." ${ }^{185}$ )

180) Rui - Finanças e políticas " $88 .$,

Américo J. Lacombe - Rui Barbasa e a $1 .^{a}$ Constituição da Repŕblica - in Digesto Econ, n. $.^{\circ} 50,79$.

Rui - Cartas doce. cit., IX, nota

182) Rui - Parecer inacabado, in Batista Pereira - Rui Barbosa e o Rio Grando

183) Rui do Sul - 44 . 4 .

184) Rui 二 Disc. no Inst. dos Advogados, 7
185) Rui 